\title{
The effects of diagenesis on the petrophysical and geochemical attributes of the Asmari Formation, Marun oil field, southwest Iran
}

\author{
J. Jafari ${ }^{1}$ - A. Mahboubi ${ }^{1}$ ' R. Moussavi-Harami ${ }^{1}$-I. S. Al-Aasm ${ }^{2}$
}

Received: 10 June 2017 / Published online: 28 February 2020

(c) The Author(s) 2020

\begin{abstract}
The distribution of good reservoir quality and its causes is the main challenges in carbonate reservoir characterization. This study investigates the effects of diagenetic processes on the reservoir quality of the carbonate successions of the Asmari Formation, in the Marun oil field, southwest Iran. The study applies an integrated approach including core petrography, petrophysical rock typing, stable carbon and oxygen isotopes as well as major and trace elements analyses. Petrographic studies and geochemical analyses express that the Asmari limestones have been affected mainly by compaction, dissolution, recrystallization, calcite and anhydrite cementation and dolomitization. Among those diagenetic overprints, dolomitization and dissolution played an important role to enhance the reservoir quality of the formation. Moreover, four types of dolomites were recognized and the rate of dolomitization increases toward the top of the Asmari carbonate successions. Possible models for dolomitization include mixing zone, brine reflux, seepage reflux and tidal pumping of seawater. Employing Flow Zone Index and Discrete Rock Type concepts led to classification of the Asmari reservoir into seven reservoir rock types. Integrating reservoir rock typing with petrographic studies and geochemical analyses also confirms that reservoir quality of the Asmari Fm. would have been mainly controlled by diagenetic processes. Moreover, stable isotopes, trace elements and facies analyses support the idea that carbonate intervals of the Asmari Formation were deposited in a warm, shallow-water environment under a saline condition.
\end{abstract}

Keywords Zagros basin · Marun oil field · Oligo-Miocene · Asmari Fm. · Diagenesis · Geochemical characteristics and Reservoir quality

\section{Introduction}

The Oligo-Miocene deposits of the Asmari Formation represent a complex sedimentary system with various lithologies (carbonates, sandstones, marls and anhydrites) and depositional geometries (Van Buchem et al. 2010). Biostratigraphy, sequence stratigraphy, diagenesis and depositional facies of the Asmari Fm. have been studied in several Iranian oil fields (e.g., Ahwaz, Aghajari, Pazanan, Parsi, Rag-e-Safid, Gachsaran, BiBi Hakimeh, Marun and Kupal oil fields) and

Edited by Jie Hao

A. Mahboubi

mahboubi@um.ac.ir

1 Department of Geology, Faculty of Science, Ferdowsi University of Mashhad, Mashhad, Iran

2 Department of Earth and Environmental Sciences, University of Windsor, Windsor, Canada outcrops (Kabir Kuh, Kuh-e-Asmari, Kuh-e-Bangestan, Khaviz, Dill, Mish and Anneh anticlines) (Adams and Bourgeois 1967; Ranjbaran et al. 2007; Al-Aasm et al. 2009; Laursen et al. 2009; Rahmani et al. 2009; Allahkarampour Dill et al. 2010; Van Buchem et al. 2010; Zabihi Zoeram et al. 2013; Avarjani et al. 2015; Shabafrooz et al. 2015).

Carbonate intervals of this formation are important hydrocarbon reservoirs, which have been producing oil and gas more than a century and reaching to the latter stages of their producing lifecycle. Therefore, an increasing interest in enhanced oil recovery methods to optimize the production has been raised recently. One of the initial stages in this process is obtaining an improved understanding of the carbonate reservoir characteristics (Van Buchem et al. 2010).

The aim of carbonate reservoir characterization is to define porosity types, reservoir heterogeneities and flow units for the purposes of reservoir simulation. Rock typing is a major step to evaluate carbonate reservoir characterization. However, this is a complex approach in carbonate 
reservoirs due to the effects of a variety of factors such as diagenesis, depositional texture and fracturing on the heterogeneity and fluid flow of these types of reservoirs (Askari and Behrouz 2011; Xu et al. 2012; Bize-Forest et al. 2014). Reservoir rock type quality depends on the either type of porosity or pore texture and the modality size of the pore throat radius for carbonate rocks (Bize-Forest et al. 2014). In the Marun oil field, texture and porosity of the carbonate successions have been significantly changed due to digenetic overprints (compaction, cementation, dissolution, dolomitization) and tectonic fracturing (Aqrawi et al. 2006; Ranjbaran et al. 2007). Although digenesis essentially affects the petrophysical attributes of the carbonate reservoirs, the importance of diagenetic processes with respect to relative sea level changes, and their effects on the flow units in the Marun oil field, has not been studied in detail.

Using routine core analyses, petrographic study of cores and thin sections as well as geochemical properties, the present paper investigates the effects of diagenetic processes, (especially, compaction, dissolution, cementation, dolomitization), and depositional texture on the petrophysical attributes of the Asmari Fm. carbonate intervals (porosity types and permeability), in order to define reservoir quality distribution and rock types.

\section{Geological setting}

\subsection{Structural setting}

The Marun anticline is located in the central part of the of the Zagros thrust belt (NE sector of the Arabian plate) (Fig. 1a). Motion of the Arabian plate toward the northeast started in the Lower Miocene, about $25 \mathrm{Ma}$ (Homke et al. 2010) or $22 \mathrm{Ma}$ (ArRajehi et al. 2010) and resulted in gentle folding of the Mesozoic to Eocene sedimentary strata in the Zagros basin (Fig. 1a, b). The first episode of folding took place during deposition of the Gachsaran Fm. evaporates, probably as a result of the initiation of continent-continent collision in the Early Miocene (Sherkati et al. 2005). Following this first phase, a period of tectonic quiescence during the Middle to Late Miocene accompanied by the deposition of the Mishan Fm. marls and lower Aghajari Fm. sandstones. The main episode of folding resulted in growth strata in upper Aghajari sandstones during the Miocene-Pliocene. The last tectonic event took place during the Pliocene-Pleistocene due to activation of reverse basement faults and resulted in the construction of the Zagros Mountains (Sherkati and Letouzey 2004; Leturmy et al. 2010). The Zagros fold-and-thrust belt (ZFTB) comprises three geographic provinces: Lurestan, Fars and the Dezful Embayment (Sepehr and Cosgrove 2004) (Fig. 1a). The ZFTB can be divided into two distinct domains from the SW to NE, with major changes in structural style and topography: (a) the Simply Folded Belt (SFB), which shows fairly regular wavelength folds that extend for hundreds of kilometers in the vicinity of the Persian Gulf (Falcon 1974; Sepehr and Cosgrove 2004; Mouthereau et al. 2006); and (b) the High Zagros, with higher elevation folding, a sharp increase in elevation and kilometer-scale throws on major thrusts. The Marun oil field is a supergiant $(6 \mathrm{~km} \times 70 \mathrm{~km})$ fault-related, asymmetric anticline, located in the central part of the Dezful Embayment province, in the SFB of the Zagros Mountains (Fig. 1a, c). The general trend of the anticline is NW-SE, parallel with the Zagros folded belt. Structural dip reaches $45^{\circ}$ and $65^{\circ}$ in the north and south flanks, respectively. It is bounded by a high angle reverse fault in the south flank.

\subsection{Stratigraphic framework}

Deposition of the Asmari Fm. occurred on the margins of a preexisting Eocene platform which surrounded a deep-water basin in which marls, shales and deep-water limestones of the Pabdeh Fm. were deposited (James and Wynd 1965) (Fig. 1a, b). In other words, Oligocene moderate to shallow-water carbonate-dominated sediments that were deposited around the edge of the preexisting Eocene platform are marked as the Asmari Formation, whereas deep-water basinal facies are assigned to the Pabdeh Formation in the center of basin (Ehrenberg et al. 2007). By progressive infilling of this basin, the Asmari platform prograded over the Pabdeh Formation so that the Asmari/Pabdeh boundary is diachronous, (Ehrenberg et al. 2007) and becoming younger basin-ward. Sedimentation of fine clastics continued in the troughs and shallow marine carbonates and evaporites to the northeast margin of the NW-SE trending Zagros basin, while coarse clastic sediments (Ahwaz Sandstone Member) were shed from the southwest (Arabian plate outcrops) into the basin during the Oligocene (Motiei 1993). The Asmari Fm. was dated Oligocene-Lower Miocene (34-18 Ma) using strontium isotopes (Ehrenberg et al. 2007). The formation comprises $314 \mathrm{~m}$ of cream- to brown-colored limestones, with thin-bedded sandstones and shales in the lower section, which overlies the Pabdeh Fm. basinal mudstone at the type locality (Motiei 1993). In the Marun oil field, the Asmari reservoir comprises $450 \mathrm{~m}$ of carbonate rocks (shallow marine, lagoonal, intertidal to sabkha mudstone to grainstones) in the middle and upper sections, and shale with sandstone and carbonate layers in the lower section (Seyrafian et al. 2011; Avarjani et al. 2015). The Asmari Fm. Carbonate sedimentation continued mainly during the Lower Miocene, followed by deposition of the lower Fars Group (Gachsaran Fm.) evaporites. Mishan and Aghajari Fm. (Middle and Upper Fars Groups) clastic sediments were deposited through the Middle Miocene to Lower Pliocene. The Pasadanian orogenic phase caused folding and thrusting 
(a)

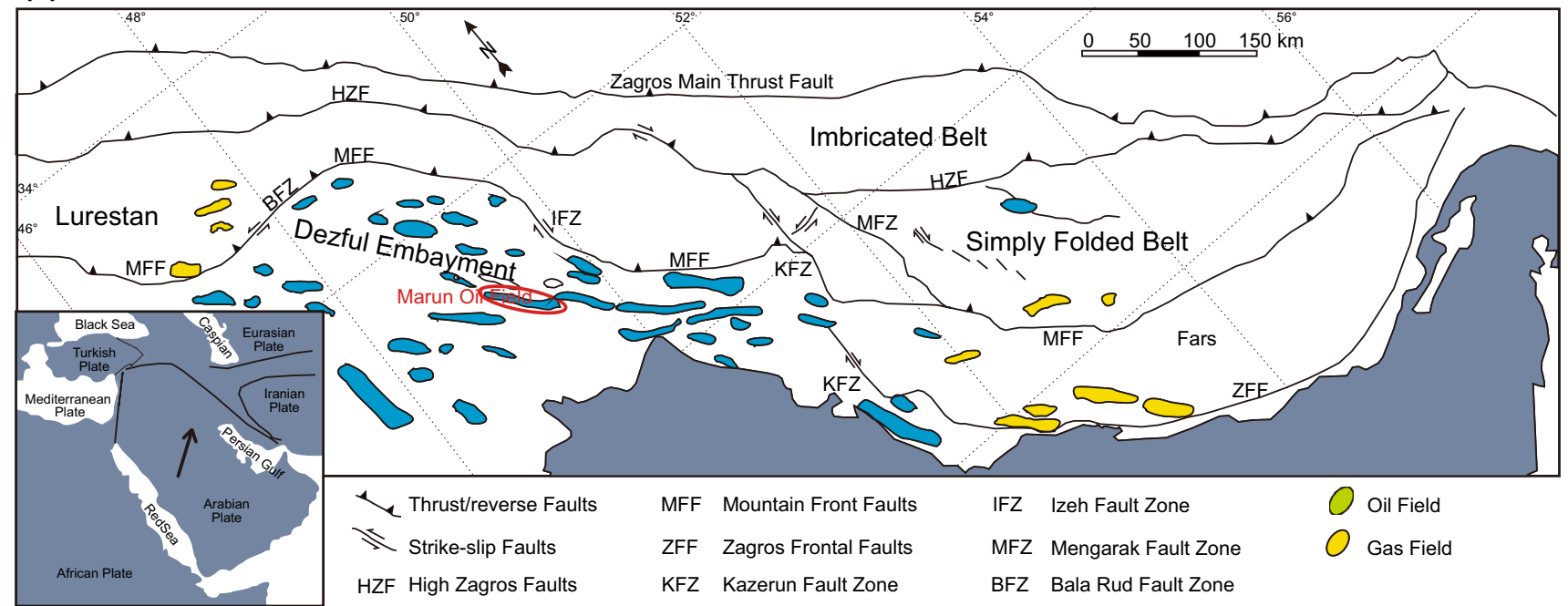

(b)

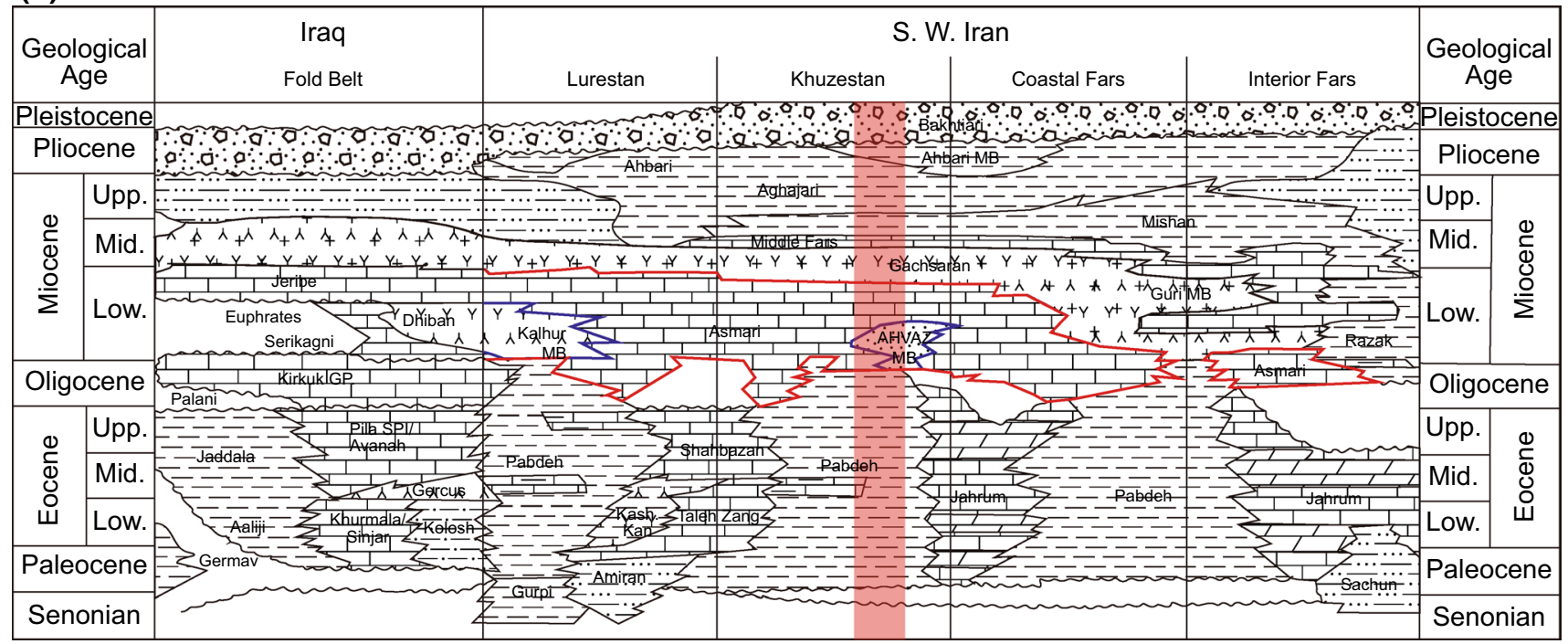

(c)

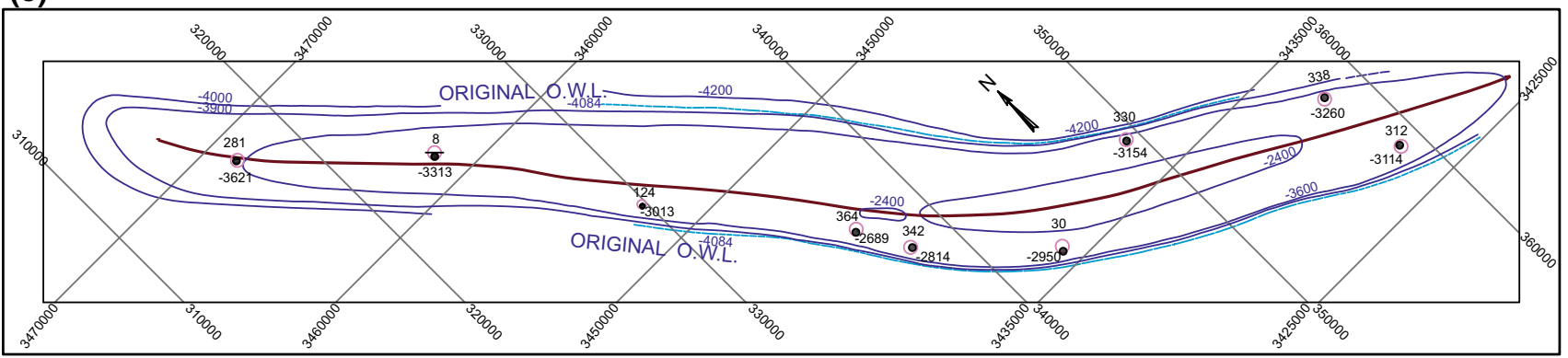

Fig. 1 a Location map Zagros province, showing structural zones and distribution of oil fields. Marun oil field is located in the center of the Dezful Embayment [adapted from Sepehr and Cosgrove (2004)]. b Cenozoic stratigraphy columns of the Zagros basin. The most representative stratigraphy column for the study area has been highlighted in light red [from Beydoun et al. (1992)]. c location of the studied wells in Marun oil field

toward the southwest of the entire sedimentary cover. Coarse clastic sediments, the Bakhtyari conglomerate, filled the syncline and other low lying areas during the Upper Pliocene to Pleistocene (James and Wynd 1965). The Bakhtyari conglomerate and Quaternary alluviums were transported from highs to the inter-mountain areas and foreland of the Zagros Orogenic Belt due to the uplift of the Zagros basin (Sherkati and Letouzey 2004) (Fig. 1a, b). 
Core Study in Well Marun \# 008

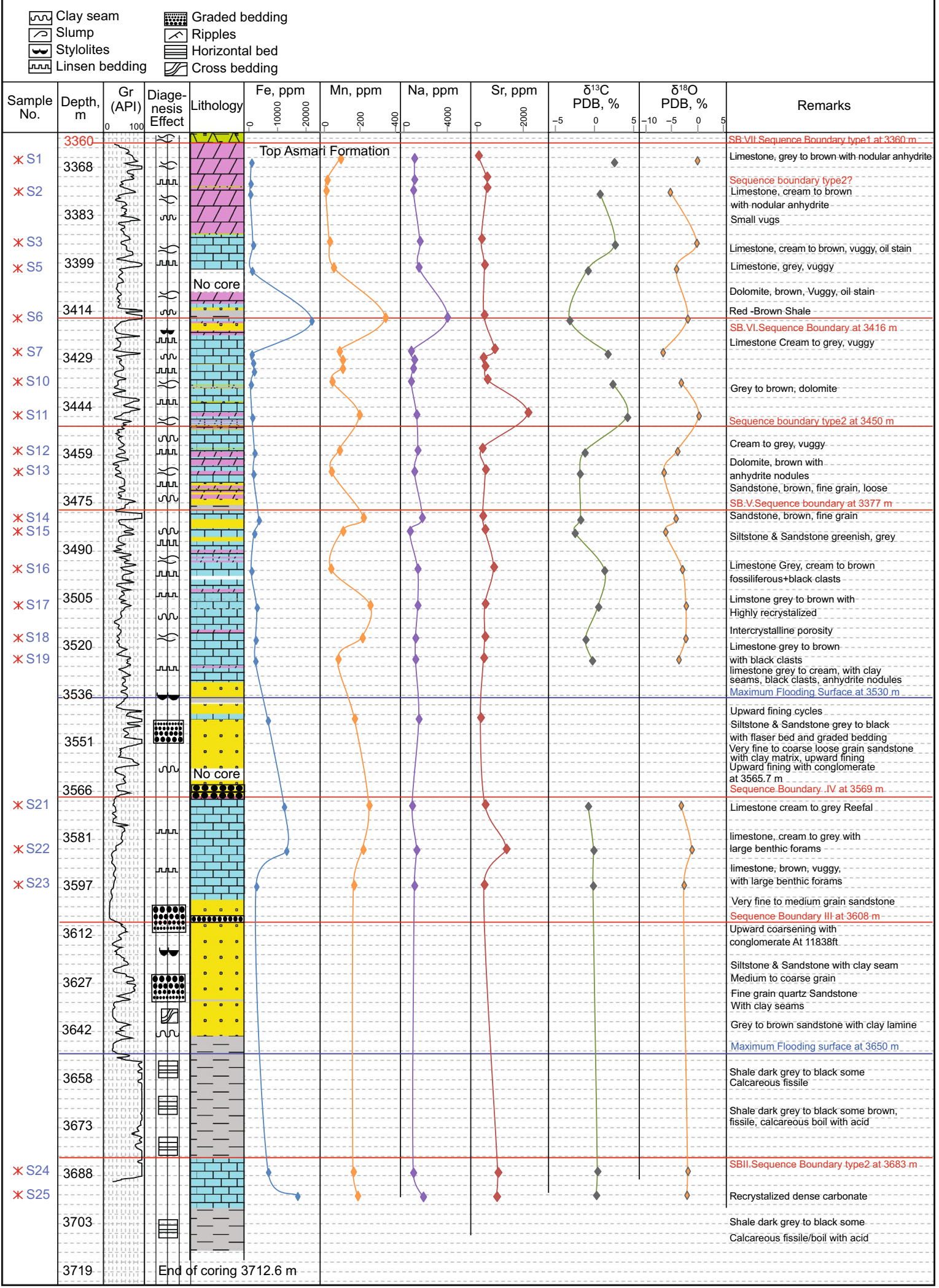

Fig. 2 Core study of the Asmari Formation in the well\#8 shows lithology, sedimentary features, sequence boundaries and variations curves of trace elements and stable isotope results 


\section{Materials and methods}

Petrographic studies were completed on 1800 thin sections from 7 wells (well numbers 8, 342, 124, 330,131, 338 and 30) (Fig. 1c). Thin sections have been stained by using alizarin red. Core samples from three wells $(450 \mathrm{~m}$ in Mn\#8, Mn\#342 and 124) were described in terms of lithology, texture and sedimentary structures, visible diagenetic features (stylolites, calcite veins, solution seams, vugs and anhydrite nodules) and ichnofossils (Fig. 2). Carbonate lithofacies were described based on Dunham (1962), Embry and Klovan (1971) and Archie (1952) classifications. Twelve samples of dolostone and limestone were examined using a LEO 1455VP scanning electronic microscope in order to discriminate texture and porosity types and sizes. Different generations of cements and dolomites were identified using a CITL-8200 MK4 cathodoluminiscence microscope, with a gun current of $400 \mu \mathrm{A}$ and $14 \mathrm{kV}$ potential difference. After detailed petrographic descriptions (Table 1), forty samples (26 samples of limestone and dolomite from well 8, six samples from well 342 and eight samples of dolomite from wells 124, 330 and 30) were selected for geochemical analyses from cores of the Asmari Fm. These samples were analyzed for major and trace element compositions ( $\mathrm{Mg}, \mathrm{Ca}, \mathrm{Sr}, \mathrm{Na}, \mathrm{Mn}$ and $\mathrm{Fe}$ ). Stable isotope $\left(\delta^{13} \mathrm{C}\right.$ and $\left.\delta^{18} \mathrm{O}\right)$ analyses were performed for 35 samples by G.G Hatch Stable Isotope Laboratory, University of Ottawa, Canada.

Samples were weighed into exetainers, $0.1 \mathrm{ml}$ of $\mathrm{H}_{3} \mathrm{PO}_{4}$ was added to the side, and exetainers were capped and helium-flushed while horizontal. Reaction at $25{ }^{\circ} \mathrm{C}$ for $24 \mathrm{~h}$ (calcite) or $50{ }^{\circ} \mathrm{C}$ for $24 \mathrm{~h}$ (dolomite) was followed by extraction in continuous flow mode. The measurements were performed on a Thermo Finnigan Delta XP and Gas Bench II. Analytical precision $(2 \sigma)$ is \pm 0.1 per mil. Data for carbon and oxygen were normalized using international standards NBS-18, NBS-19 and LSVEC (C only). Porosity and permeability data of core plugs were obtained from NIOC data base in order to investigate reservoir quality and rock type. Winland R35 and FZI methods were used for reservoir rock type classifications.

\section{Results}

\subsection{Petrographic evidences of diagenetic features}

Petrographic descriptions of thin sections show that the Asmari Fm. is composed mainly of limestones (mudstones to grainstones with calcite cement), and very fine to coarse crystalline dolomites, with intervals of sandy dolomites and sandstones with calcite, dolomite and anhydrite cements (Figs. 2, 3, 4). Stratigraphy and brief petrographic descriptions of cores and selected samples are provided in Table 1 and Figs. $1 \mathrm{~b}$ and 2.

The main diagenetic processes that have affected the Asmari limestones are compaction, stylolitization, dissolution, calcite cementation and dolomitization. Additional processes including micritization of bioclasts, anhydrite cementation, bioturbation, pyrite formation and neomorphism are common. Vertical distributions of diagenetic processes in the Asmari reservoir are presented in Fig. 4.

The main diagenetic processes that affected the Asmari reservoir quality are described below.

\subsubsection{Compaction}

Stylolitization as firm evidence for compaction can be seen throughout the Asmari Fm. Macro- and micro-scale stylolites occurred mainly parallel to the bedding plane in the upper portions of the Asmari Fm., with some oblique stylolites present in lower sections (Fig. 2). Clay seams, silt size quartz grains and organic materials are visible along stylolite surfaces (Fig. 3a1, a2, d1). The stylolites can be closed or semi-open, creating permeability barriers for hydrocarbon migration within the dense, argillaceous limestone intervals of the Asmari reservoir. Evidence for compaction is also provided by interlocked grain contacts seen in grainstones and sandstones (Fig. 3a3). The amount of porosity reduces in limestones and dolomites with increasing burial depth and overburden pressure generally (Fig. 5).

\subsubsection{Cementation}

Calcite cementation comprises both an earlier phase of finely crystalline, isopachous cement that lines pore walls and grain surfaces (Fig. 3b1), and a later phase of coarser, blocky spar that fills former pore volumes not completely filled by the fine cement linings that are common in limestone intervals (Fig. 3b1, b2, b6). Blocky calcite cement also occurs, filling former moldic pores in some dolostone samples (Fig. 3b2, b6). Concave meniscus, isopachous equant spary calcite and syntaxial overgrowth cements are very common in sandstones (Fig. 3b4, b6, b8). Fine to medium, crystalline dolomite cement has filled the intergranular porosity of sandstones as well as moldic and fracture porosities (Fig. 3b3, b6). In sandstones, two phases of siliceous cement are visible: (a) pore filling; and (b) quartz overgrowth, both of which have resulted in porosity reduction (Fig. 3a3, b8). Anhydrite cement occurs mainly as filling fractures and porosities in carbonates, and intergranular porosity of sandstones especially in the upper sections of the Asmari Fm (Fig. 3b5). Anhydrite can also occur as nodules and patches (Fig. 3d2). 
Table 1 Stratigraphic position and brief petrography description of selected samples for geochemical analysis

\begin{tabular}{|c|c|c|c|c|c|c|}
\hline \multirow{2}{*}{$\begin{array}{l}\text { Sample } \\
\text { no. }\end{array}$} & \multirow[t]{2}{*}{ Well no. } & \multirow[t]{2}{*}{ Depth, m } & \multicolumn{2}{|c|}{ Isotope results } & \multirow[t]{2}{*}{ Sample petrography description } & \multirow[t]{2}{*}{ Sedimentary environment } \\
\hline & & & $\delta^{13} \mathrm{C}, \%$ & $\delta^{18} \mathrm{O}, \%$ & & \\
\hline 1 & 8 & 3365.44 & 2.4 & -0.2 & Dolomite, fine crystalline with anhydrite patches & Sabkha \\
\hline 2 & 8 & 3372.14 & & & Limestone, wackestone to packstone & Lagoon \\
\hline 3 & 8 & 3375.50 & 0.6 & -5.4 & Limestone, packstone & Lagoon \\
\hline 4 & 8 & 3391.65 & 2.5 & -0.3 & Dolomite, fine crystalline, & Supratidal \\
\hline 5 & 8 & 3399.88 & -0.9 & -4.2 & Limestone, wackestone, dolomitic & Lagoon \\
\hline 6 & 8 & 3415.73 & -3.3 & -2.0 & Limestone, wackestone, dolomitic & Lagoon \\
\hline 7 & 8 & 3426.39 & 1.6 & -6.8 & $\begin{array}{l}\text { Limestone, wackestone to packstone with ooids and } \\
\text { calcite cement }\end{array}$ & Shallow marine \\
\hline 8 & 8 & 3429.14 & & & $\begin{array}{l}\text { Limestone, packstone with pelloid and ooid and calcite } \\
\text { cement }\end{array}$ & Shallow marine \\
\hline 9 & 8 & 3431.88 & & & $\begin{array}{l}\text { Limestone, packstone with pelloid and ooid and calcite } \\
\text { cement }\end{array}$ & Shallow marine \\
\hline 10 & 8 & 3436.00 & 2.2 & -3.3 & Limestone, ooid grainstone with calcite cement & Shallow marine \\
\hline 11 & 8 & 3446.51 & 4.1 & 0.1 & Secondary dolomite, fine crystalline & \\
\hline 12 & 8 & 3457.79 & -1.3 & -4 & $\begin{array}{l}\text { Limestone, bioclastic wackestone to packstone, dolomitic } \\
\text { with calcite cement }\end{array}$ & Lagoon \\
\hline 13 & 8 & 3464.49 & -1.9 & -6.6 & Limestone, packstone to grainstone, calcitic and dolomitic & Lagoon \\
\hline 14 & 8 & 3479.12 & -1.9 & -4.3 & Limestone, boundstone, dolomitic & Shallow marine \\
\hline 15 & 8 & 3483.39 & -2.6 & -6.3 & Limestone, wackestone with calcite cement & Lagoon \\
\hline 16 & 8 & 3495.28 & 1.2 & -3.1 & Limestone, bioclastic packstone, dolomitic, calcite cement & Lagoon \\
\hline 17 & 8 & 3506.86 & 0.4 & -2.4 & Secondary dolomite, medium to coarse crystalline & \\
\hline 18 & 8 & 3517.22 & -1.2 & -2.4 & $\begin{array}{l}\text { Limestone, wackestone, dolomitic, fine crystalline, with } \\
\text { calcite cement }\end{array}$ & Lagoon \\
\hline 19 & 8 & 3523.93 & -0.4 & -3.8 & Limestone, bioclastic, packstone, pelletic, with calcite & Lagoon \\
\hline 20 & 8 & 3542.82 & & & $\begin{array}{l}\text { Limestone, bioclastic packstone, pelletic dolomitic fine } \\
\text { crystalline, with calcite. sandy }\end{array}$ & Beach to lagoon \\
\hline 21 & 8 & 3570.25 & -0.9 & -3.3 & Limestone, boundstone, with calcite cement & Shallow marine \\
\hline 22 & 8 & 3584.27 & -0.2 & -1.2 & Secondary dolomite, fine crystalline & Shallow marine \\
\hline 23 & 8 & 3595.55 & -0.3 & -2.8 & $\begin{array}{l}\text { Limestone, grainstone to boundstone, micritic, with calcite } \\
\text { cement }\end{array}$ & Shallow marine to shelf edge \\
\hline 24 & 8 & 3686.38 & 0.3 & -2.0 & $\begin{array}{l}\text { Limestone, wackestone to packstone, recrystallized with } \\
\text { calcite cement, dolomitic, pyritic }\end{array}$ & Shelf edge-slope \\
\hline 25 & 8 & 3694.00 & 0.1 & -2.2 & $\begin{array}{l}\text { Limestone, bioclastic packstone to grainstone, recrystal- } \\
\text { lized with calcite cement, dolomitic, pyritic }\end{array}$ & Shelf edge-slope \\
\hline 26 & 8 & 3698.26 & & & $\begin{array}{l}\text { Limestone, bioclastic packstone to grainstone, recrystal- } \\
\text { lized with calcite cement, dolomitic, pyritic }\end{array}$ & Shelf edge-slope \\
\hline 27 & 342 & 3086.00 & 2.3 & -0.7 & Dolomite, fine crystalline with anhydrite & Supratidal \\
\hline 28 & 342 & 3117.00 & 1.7 & 0.1 & Secondary dolomite, medium to coarse crystalline & Lagoon \\
\hline 29 & 342 & 3157.00 & 0.1 & 0.2 & Secondary dolomite, medium to coarse crystalline & Lagoon \\
\hline 30 & 342 & 3175.00 & 0.2 & -0.9 & Limestone, wackestone, dolomitic & Lagoon \\
\hline 31 & 342 & 3176.00 & 0.5 & -0.2 & Secondary dolomite, fine crystalline with anhydrite & Lagoon \\
\hline 32 & 342 & 3183.00 & 0.5 & -1.2 & $\begin{array}{l}\text { Secondary dolomite, fine to medium crystalline with } \\
\text { anhydrite }\end{array}$ & Lagoon \\
\hline 33 & 124 & 3174.35 & 1.3 & 2.1 & $\begin{array}{l}\text { Bioclastic wackestone, dolomitic with anhydrite and } \\
\text { calcite cement }\end{array}$ & Lagoon \\
\hline 34 & 124 & 3166.00 & 4.3 & 0.0 & $\begin{array}{l}\text { Secondary dolomite, fin to medium crystalline, pelletic, } \\
\text { sandy, recrystallized with calcite cement and anhydrite, } \\
\text { intercrystalline and solution porosity }\end{array}$ & Lagoon \\
\hline 35 & 124 & 3203.75 & 0.5 & 0.3 & $\begin{array}{l}\text { Secondary dolomite, fine crystalline, pelletic, sandy, } \\
\text { recrystallized with calcite cement and anhydrite, inter- } \\
\text { crystalline and solution porosity }\end{array}$ & Lagoon \\
\hline
\end{tabular}


Table 1 (continued)

\begin{tabular}{|c|c|c|c|c|c|c|}
\hline \multirow{2}{*}{$\begin{array}{l}\text { Sample } \\
\text { no. }\end{array}$} & \multirow[t]{2}{*}{ Well no. } & \multirow[t]{2}{*}{ Depth, m } & \multicolumn{2}{|c|}{ Isotope results } & \multirow[t]{2}{*}{ Sample petrography description } & \multirow[t]{2}{*}{ Sedimentary environment } \\
\hline & & & $\delta^{13} \mathrm{C}, \%$ & $\delta^{18} \mathrm{O}, \%$ & & \\
\hline 36 & 124 & 3139.35 & 3.7 & 1.0 & $\begin{array}{l}\text { Dolomite, fine crystalline with solution porosity, bioclastic } \\
\text { wackestone to packstone }\end{array}$ & Lagoon \\
\hline 37 & 330 & 3520.50 & 2.3 & -0.1 & $\begin{array}{l}\text { Secondary dolomite, fine to medium crystalline with } \\
\text { anhydrite }\end{array}$ & Lagoon \\
\hline 38 & 30 & 3223.71 & 0.7 & 0.6 & $\begin{array}{l}\text { Secondary dolomite, medium to coarse crystalline, barren } \\
\text { of fossil }\end{array}$ & Lagoon \\
\hline 39 & 30 & 3264.25 & 0.9 & -0.9 & $\begin{array}{l}\text { Secondary dolomite, fine to medium crystalline }+ \text { lime- } \\
\text { stone dolomitic }\end{array}$ & Lagoon \\
\hline 40 & 30 & 3304.79 & 2.5 & 0.2 & $\begin{array}{l}\text { Secondary dolomite, medium to coarse crystalline with } \\
\text { solution and intercrystalline porosity }\end{array}$ & Lagoon \\
\hline
\end{tabular}

\subsubsection{Dissolution and fracturing}

Skeletal and non-skeletal grains within the carbonate matrix have been widely affected by dissolution processes, which have resulted in increasing porosity. The evidence for this can be seen as solution vuggy porosity in mudstones and dolostones (Fig. 3c1, c2, c5). Dissolution has affected essentially all bioclasts of presumed original aragonite composition: coral fragments, mollusk shells and green algae. The moldic porosity formed by dissolution varies greatly in abundance from bed to bed, due to variations in bioclasts proportions and calcite cementation. Extensive dissolution of all types of bioclasts (including non-aragonite types) is especially common in dolostones, producing a distinctive micro-vuggy fabric (Fig. 3c5, c6). Much larger ( $\geq \mathrm{cm}$ scale) dissolution cavities and fissures, typically filled with sand or granular carbonate sediment, are associated with inferred karsts surfaces (Figs. 2, 3d1). These karsts features occur in limestone beds within 1-3 m below the type 1 sequence boundaries (namely sequence boundaries V and VI) introduced by Van Buchem et al. (2009) (Figs. 2, 3d). Minor, sometimes open, fractures affecting both limestones and dolostones are present, while other fractures are partly to completely seal by anhydrite or calcite (Fig. 3c4).

\subsubsection{Dolomitization}

Dolomitization has widely affected the limestones in the middle and upper sections of the Asmari Fm. The rate of dolomitization increases from the lower to upper units of this formation; however, the crystal size decreases in an upwards direction (Figs. 2, 6). Dolomite crystal sizes range from very fine to very coarse, have a unimodal to polymodal distribution and are euhedral planar to planar-s and xenomorphic (e.g., Sibley and Gregg 1987). Generally, four types of dolomites are recognized: (1) Type I-very fine to fine crystalline, unimodal, planar to planar-s with crystal size $<20 \mu \mathrm{m}$ (Figs. 6a, 7a); (2) Type II-fine to medium dolomite, crystal size $<100 \mu \mathrm{m}$ polymodal, planar to planar-s (Figs. 6b, 7b); (3) Type III-medium to very coarse crystalline polymodal, subhedral to xenotopic crystal size $20 \mu \mathrm{m}<d<300 \mu \mathrm{m}$ (Fig. 6c, 7c); and (4) Type IV-coarse to very coarse crystalline, crystal size $100 \mu \mathrm{m}<d$ or saddle dolomite (Fig. 6d, 7d). The last type of dolomite can be seen as disperse medium to coarse crystals in fractures and as fabric selective replacement in mudstones (Figs. 3, 7).

\subsection{Trace elements and stable isotope data}

The results of trace elements and stable isotopes $\left(\delta^{13} \mathrm{C}\right.$ and $\delta^{18} \mathrm{O}$ ) are shown in Tables 1 and 2 . The $\delta^{18} \mathrm{O}$ and $\delta^{13} \mathrm{C}$ values of the Asmari Fm. dolomites range from -2.4 to $2.1 \%$ o VPDB and -0.2 to $4.3 \%$ VPDB, respectively.

The values of $\delta^{13} \mathrm{C}$ and $\delta^{18} \mathrm{O}$ in limestones (mudstone to grainstone) range from -6.8 to $-0.2 \%$ VPDB and -3.3 to $2.5 \%$ o VPDB, respectively. The Mg concentration ranges between 5.5 and $11.2 \%$ by weight in dolomites and increases upward (Fig. 8), but is less than 3.5\% in dolomitic limestones.

A general positive trend can be seen between $\mathrm{Mn}$ and Fe molar concentrations (Fig. 9), with $\mathrm{Mn}$ and Fe values generally increasing with depth; however, there is no relationship between dolomite type and molar concentrations of $\mathrm{Mn}$ and $\mathrm{Fe}$ (Fig. 8 and Table 2). These values culminated

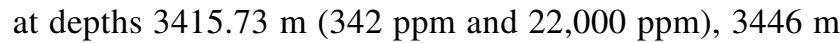
(195 ppm and $1100 \mathrm{ppm}), 3479 \mathrm{~m}$ (218 ppm and $3400 \mathrm{ppm})$ and $3570-84 \mathrm{~m}(250-216 \mathrm{ppm}$ and $12,300-13,100 \mathrm{ppm})$ in Well\#8. The concentration of $\mathrm{Zr}$ and $\mathrm{Ti}$ also increases in proportion to $\mathrm{Mn}$ and $\mathrm{Fe}$ concentrations. The average values of $\mathrm{Fe}, \mathrm{Mn}$ and $\mathrm{Sr}$ for dolomites (4119 ppm, $102 \mathrm{ppm}, 586 \mathrm{ppm}$ ) are greater than those values for limestone $(2870 \mathrm{ppm}$, $71 \mathrm{ppm}, 271 \mathrm{ppm}$ ) (Table 2). No meaningful variation of $\mathrm{Mn} / \mathrm{Sr}$ ratios values occurs with depth. Peak $\mathrm{Sr}$ concentrations co-vary in accordance with $\mathrm{Mg}$ concentrations (Figs. 2, $9)$. 

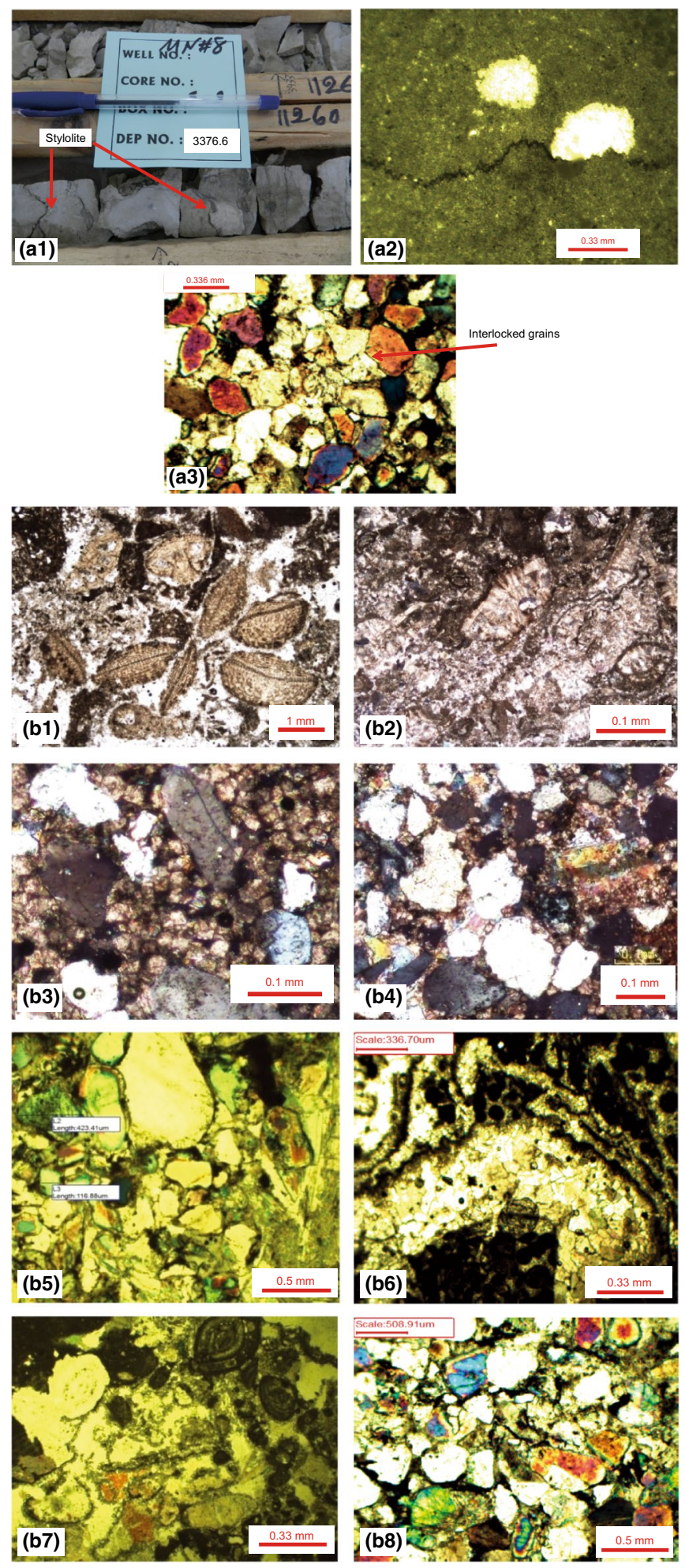

Fig. 3 a Diagenetic processes, compaction, a1 stylolites in mudstone, well\#8 depth $3431.88 \mathrm{~m}$; a2 microstylolites in mudstone, well\# 8 depth $3376.71 \mathrm{~m}$, XPL; a3 compaction (Interlocked grains contacts) and anhydrite cement in sandstones, well\#131 depth $3437.6 \mathrm{~m}$, XPL. b Cementation, b1 calcite rim cement in grainstones; b2 spary calcite cement filled fossil tests, well\#8, depth $3506.85 \mathrm{~m}$; b3, dolomite cement in sandstones, Well\#30, depth $3223.71 \mathrm{~m}$; b4, intergranular meniscus siliceous cement in sandstones, well\#30, depth 3345.93; b5, anhydrite cement in sandstones, well\#8 depth 3409.93 m X2; b6, Spary calcite cement filled moldic porosity, well\#330, depth 3367 m; b7, Neomorphism; b8, overgrowth siliceous cement in sandstones. c Dissolution; c1, solution porosity in dolomitic mudstone, well\#8, depth $3359.34 \mathrm{~m}$; c2, vuggy porosity in dolomite and filling of dissolved bioclasts by calcite cement, well\#8, depth $3446.51 \mathrm{~m}$; c3, micritization of skeletal grains and calcite cementation, well\#8, depth 3457.48 m, well\#8, depth 3505.33 m; c4, Fracture in wackestone; c5, Solution and intercrystalline porosity in dolomite and c6, Core with vuggy porosity in dolomite (d) d1 Karstification, brecciation and solution seams, well\#8, depth $3429.44 \mathrm{~m} ; \mathbf{d 2}$, Red and green marl near sequence boundary Type 1, well\#8, depth $3415.42 \mathrm{~m}$ 

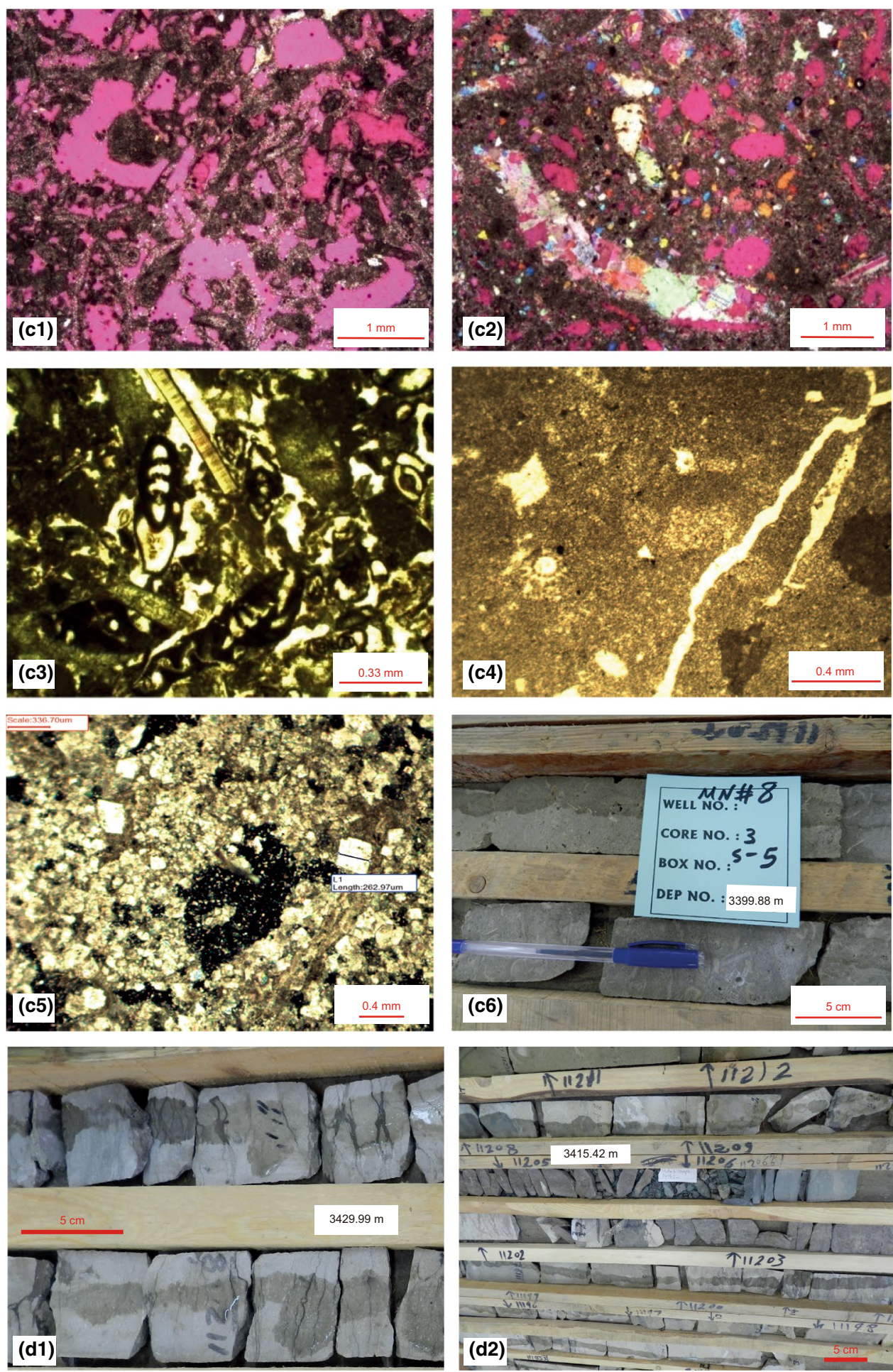

Fig. 3 (continued)

\subsection{Reservoir rock types}

The main aim of reservoir rock typing is recognition of hydraulic units of reservoir with similar fluid flow properties (citation). Four rock groups were distinguished in the
Asmari reservoir based on variations of porosity and permeability from cross-plots (Fig. 10c, d). These groups correspond to four carbonate reservoir rock types: Rock Type 1 (very poor to poor reservoir quality) with porosity $<4 \%$ and permeability $<0.1 \mathrm{md}$; Rock Type 2 (fair reservoir quality) 


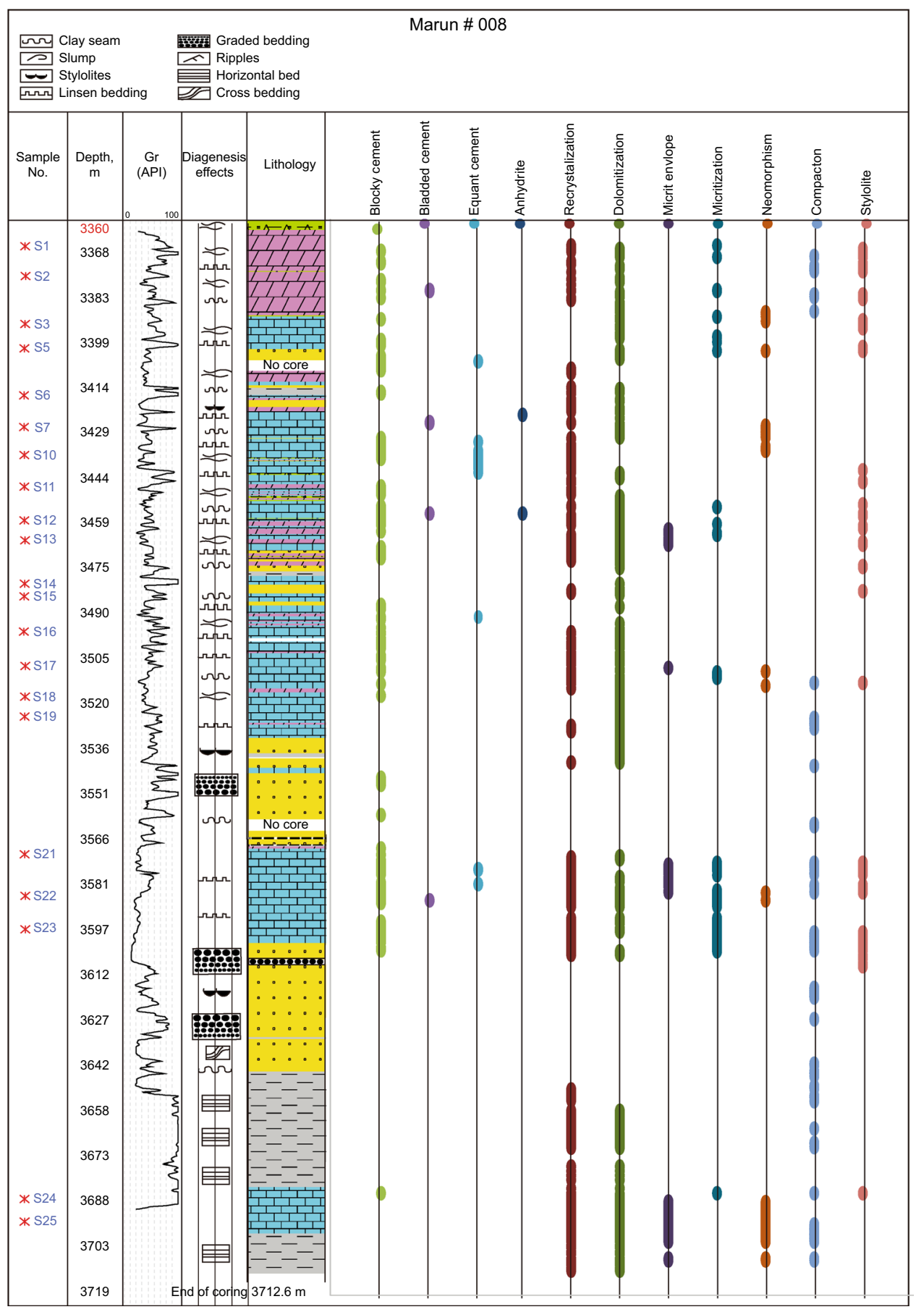

Fig. 4 Vertical distribution of diagenetic processes in the Asmari Formation

with $4 \%<$ porosity $<10 \%$ and $0.1 \mathrm{md}<$ permeability $<2$ md; Rock Type 3 (good reservoir quality) with $10 \%<$ porosity $<15 \%$ and $2 \mathrm{md}<$ permeability $<10 \mathrm{md}$; and Rock Type 4 (very good reservoir quality) with porosity $>15 \%$ and permeability $>10 \mathrm{md}$.

Using the Winland R35 method, with a pore aperture corresponding to the 35 th percentile of mercury saturation in a mercury injection test, four reservoir rock types are recognized (Fig. 11b): (1) Flow unit 1 (pore throat radius $<0.2 \mu \mathrm{m}$ ) with porosity $<5 \%$ and permeability $<0.02 \mathrm{md}$; (2) Flow unit $2(0.2 \mu \mathrm{m}<$ pore throat radius $<2 \mu \mathrm{m}$ ) with $1 \%<$ porosity $<15 \%$ and 0.02 md $<$ permeability $<2 \mathrm{md}$; (3) Flow unit $3(2 \mu \mathrm{m}<$ pore throat radius $<10 \mu \mathrm{m}$ ) with $3 \%<$ porosity $<25 \%$ and 2 $\mathrm{md}<$ permeability $<20 \mathrm{md}$; and (4) Flow unit 4 (pore 


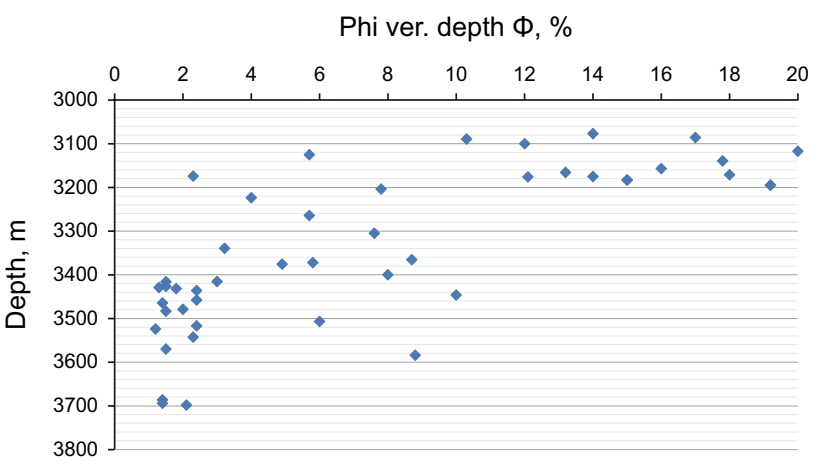

Fig. 5 Porosity variation versus depth in the Asmari reservoir, Marun oil field

throat radius $>10 \mu \mathrm{m}$ ) with porosity $>5 \%$ and permeability $>10 \mathrm{md}$.

In the present paper, hydraulic units are calculated based on the FZI method (Kozeny 1927; Amaefule et al. 1993), and the complementary DRT method using the following equations (Abedini 2011).

$\mathrm{RQI}=0.0314 \cdot \sqrt{ } k / \phi$

$\mathrm{FZI}=\mathrm{RQI} / \phi z$

$\phi z=\phi / 1-\phi$

DRT $=\operatorname{Round}(2 \ln (\mathrm{FZI})+10.6)$

where RQI is the rock quality index $(\mu \mathrm{m}), k$ is permeability $(\mathrm{md}), \phi$ is effective porosity ( $\mathrm{v} / \mathrm{v}), \phi z$ is normalized porosity, and FZI is the Flow Zone Index $(\mu \mathrm{m})$. The results of calculations are presented in Table 3.

The $\log -\log$ plot of RQI versus normalized porosity shows six regression lines and one point, which correspond to seven reservoir rock types (Fig. 11a, b). The FZI, RQI, DRT values and extracted reservoir rock types are shown in Table 3.

Rock types 1, 2 and 3 are mainly comprised of dolomite types of I, II and III. Rock types 4, 5 and 6 encompass a variety of limestone textures (mudstone, wackestone, packstone, grainstone, boundstone and some dolomite samples (Table 3).

\section{Discussion}

\subsection{Implications for paleoenvironments}

The middle section of the Asmari Fm. is composed mainly of packstones, grainstones and boundstones, with mudstone to wackestones and dolomites in the upper sections (Figs. 2, 3 and Table 3).

The microfacies which have been recognized in the Asmari Fm. suggest that deposition occurred in the spectrum of different depositional environments from coastal and peritidal settings to shallow marine environment. (e.g., Flügel 2004; Vaziri-Moghaddam et al. 2006). The depositional texture of the Asmari Fm. was affected by several digenetic processes during marine to burial and subaerial conditions (Figs. 2, 3, 4).

Stable isotope values vary between -6.8 and $2.0 \%$ PDB for $\delta^{18} \mathrm{O}$ and -3.3 to $4.3 \%$ PDB for $\delta^{13} \mathrm{C}$ (Table 2). Samples were divided into two groups ( $\mathrm{A}$ and $\mathrm{B}$ ) based on stable isotope values in order to recognize depositional and diagenetic paleoenvironments (Fig. 12). The characteristics of these two paleoenvironments are described below.

\subsubsection{Depositional environment}

The first group (group A) of samples comprises the least altered limestones and dolomites, with near zero or positive values of $\delta^{18} \mathrm{O}$ and $\delta^{13} \mathrm{C}$. These samples suggest warm shallow marine and evaporitic conditions for the Asmari carbonates deposition (Fig. 12) (Adabi and Rao 1991; Swart 2015).

Modern tropical aragonitic sediments have low $\mathrm{Mn}(<20 \mathrm{ppm})$, moderate $\mathrm{Na}(2500 \mathrm{ppm})$ and high $\mathrm{Sr}$ $(10,000 \mathrm{ppm})$ concentrations. In contrast, modern temperate calcite sediments contain low $\mathrm{Sr}(\sim 3000 \mathrm{ppm})$, high $\mathrm{Na}(\sim 5000 \mathrm{ppm})$ and $\mathrm{Mn}(\sim 150 \mathrm{ppm})$ concentrations (Rao 1986). In the present study, the average concentrations for trace elements ( $\mathrm{Sr}, \mathrm{Na}$ and $\mathrm{Mn}$ ) are $\sim 411 \mathrm{ppm}, \sim 1175 \mathrm{ppm}$ and $\sim 124 \mathrm{ppm}$, respectively (Table 2, Fig. 9). The $\mathrm{Sr} / \mathrm{Na}$ ratio is about 0.4 , while it is $\sim 0.7$ for modern temperate calcite sediments and high ( 4.0) in aragonitic carbonates. Thus, the geochemical properties of the Asmari carbonate sediments in Marun oil field differ from recent tropical carbonates, and there is no exact correlation with modern temperate carbonate sediments (Fig. 9). The Sr-Mn data support the results of stable isotope analysis which suggested that the Asmari Fm. was deposited in warm, shallow marine conditions (Fig. 9).

The general increase in $\mathrm{Fe}$ and $\mathrm{Mn}$ concentrations at drilling depths more than $3450 \mathrm{~m}$ might be due to redox conditions and pore fluid sources (Al-Aasm 2000) (Fig. 8). Widespread high $\mathrm{Fe}$ values (>1000 ppm) and/or high $\mathrm{Mn}$ $(>50 \mathrm{ppm}$ ) could indicate that the pore waters were reducing in a media with significant source of $\mathrm{Fe}$ and/or Mn, such as soil horizons, underlying volcanic or detrital siliciclastics was present (Budd 1997; Azmy et al. 2001). Although some authors believe that high concentrations of Fe and Mn may occur due to recrystallization in dolomites (cf. Banner et al. 1988), however, results from the present study show that $\mathrm{Fe}$ 

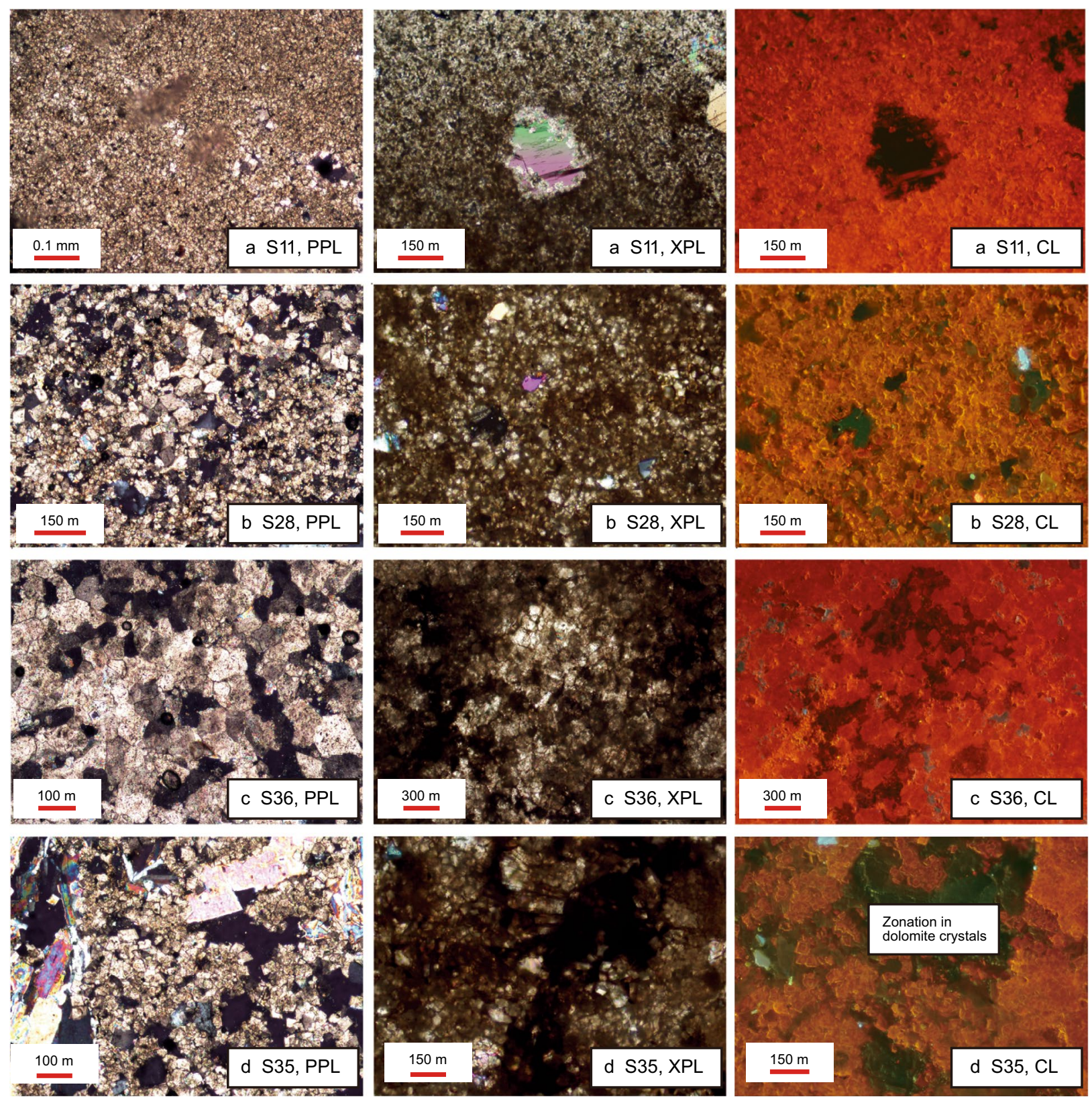

Fig. 6 Dolomite types in the Asmari Formation Marun oil field. a type I (very fine to fine crystalline unimodal, dolomicrite, ( $\mathrm{S} 1 *$ and $\mathrm{S} 11$, well\#8, depth $3359.34 \mathrm{~m}$, XPL); b type II (fine to medium crystal size, polymodal, planar to planar-s, S28, well\#342, Depth 3117 m, S40 Well\#330, Depth $3415.2 \mathrm{~m}$ ); c type III (medium to very coarse crystalline polymodal, Planar-s to xenotopic, S36, Well\#124, Depth $3166 \mathrm{~m}$ and S41, Well\#330, Depth $3520.5 \mathrm{~m}$ ) and d type IV (coarse to very coarse crystalline with zoning, saddle dolomite, S35, Well\#124, depth $3174.35 \mathrm{~m})$. (*The reference for Sample no. is in Table 2)

and $\mathrm{Mn}$ values of analyzed samples have not been affect by the type and crystal size of dolomites.

\subsubsection{Diagenetic environments}

The second group (group B) of samples with depleted values of $\delta^{18} \mathrm{O}$ and $\delta^{13} \mathrm{C}$ mark the effects of subaerial, vadose and phreatic diagenetic zones (Fig. 12) (Lohmann 1988; 

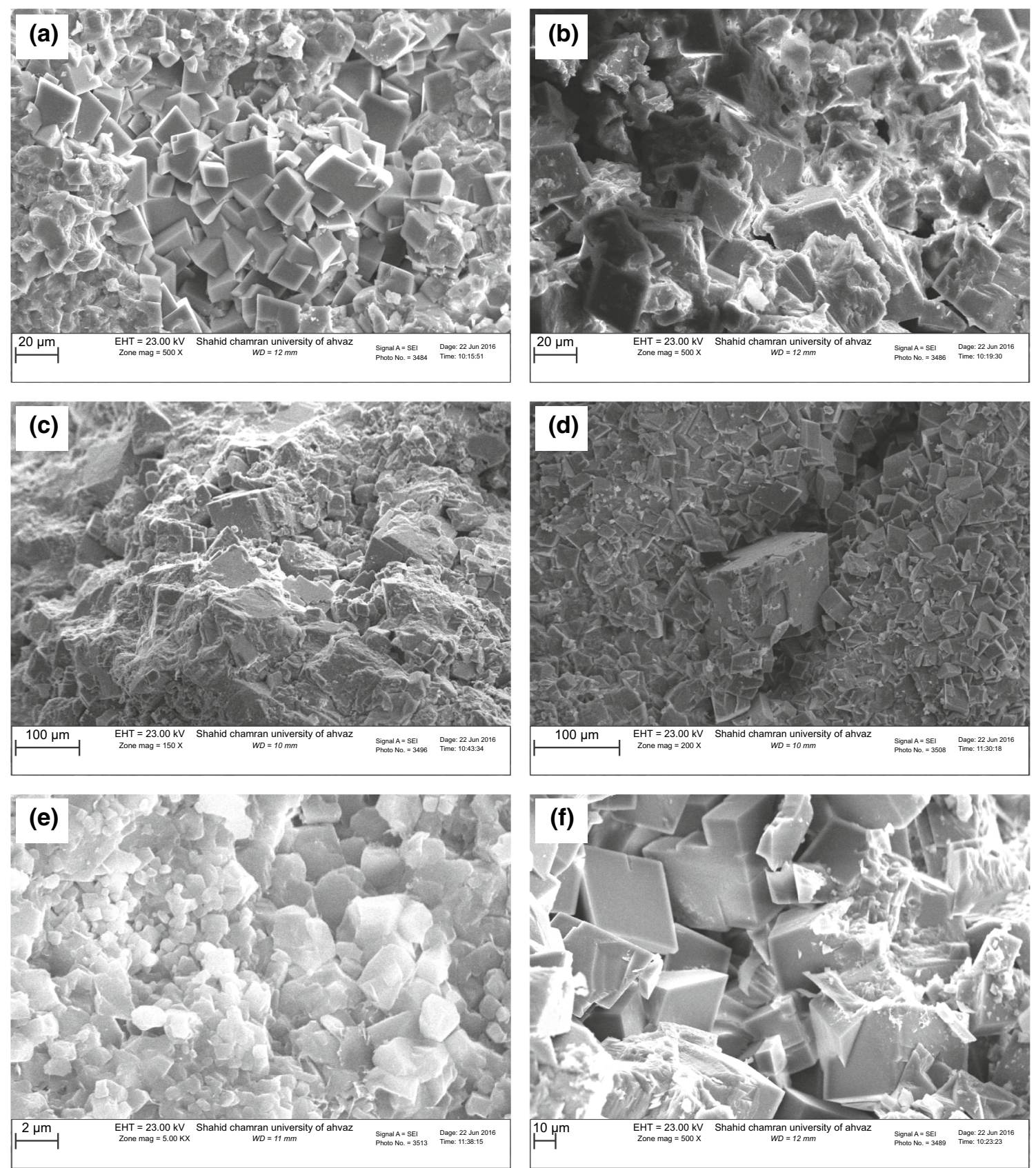

Fig. 7 SEM photos showing different types of dolomites and porosity sizes in dolomites and limestones. A Type I, B TypeII, C TypeIII and D TypeIV, E Intergranular microporosity in dolomitic limestones, $\mathbf{F}$ Intercrystalline macro-porosity in dolomites

Swart 2015). The covariance relationship between Mn and Fe values at certain drilling depths $(3415.73 \mathrm{~m}, 3446 \mathrm{~m}$, $3479 \mathrm{~m}$ and $3570-84 \mathrm{~m}$ in Well\#8), (Figs. 8, 9) can be related to the effect of subaerial exposure, weathering and the presence of soil horizons (e.g., Budd 1997). This relationship coincides with the sequence boundaries defined by the core study (Figs. 2, 3d and Table 2). Furthermore, $\mathrm{Sr}$ values culminate near the above-mentioned depths and could confirm the presence of subaerial weathering. The covariance of $\mathrm{Sr}$ with $\mathrm{Mg}$ is related presumably to the evaporative conditions at lowstand systems tract (Figs. 2, 8 and Table 2).

\subsection{Diagenetic processes sequences}

The Zagros folding episode started in the early Miocene, but the main orogenic phase is presumed to take place in the Plio-Pliestocene (Sherkati and Letouzey 2004; Leturmy 


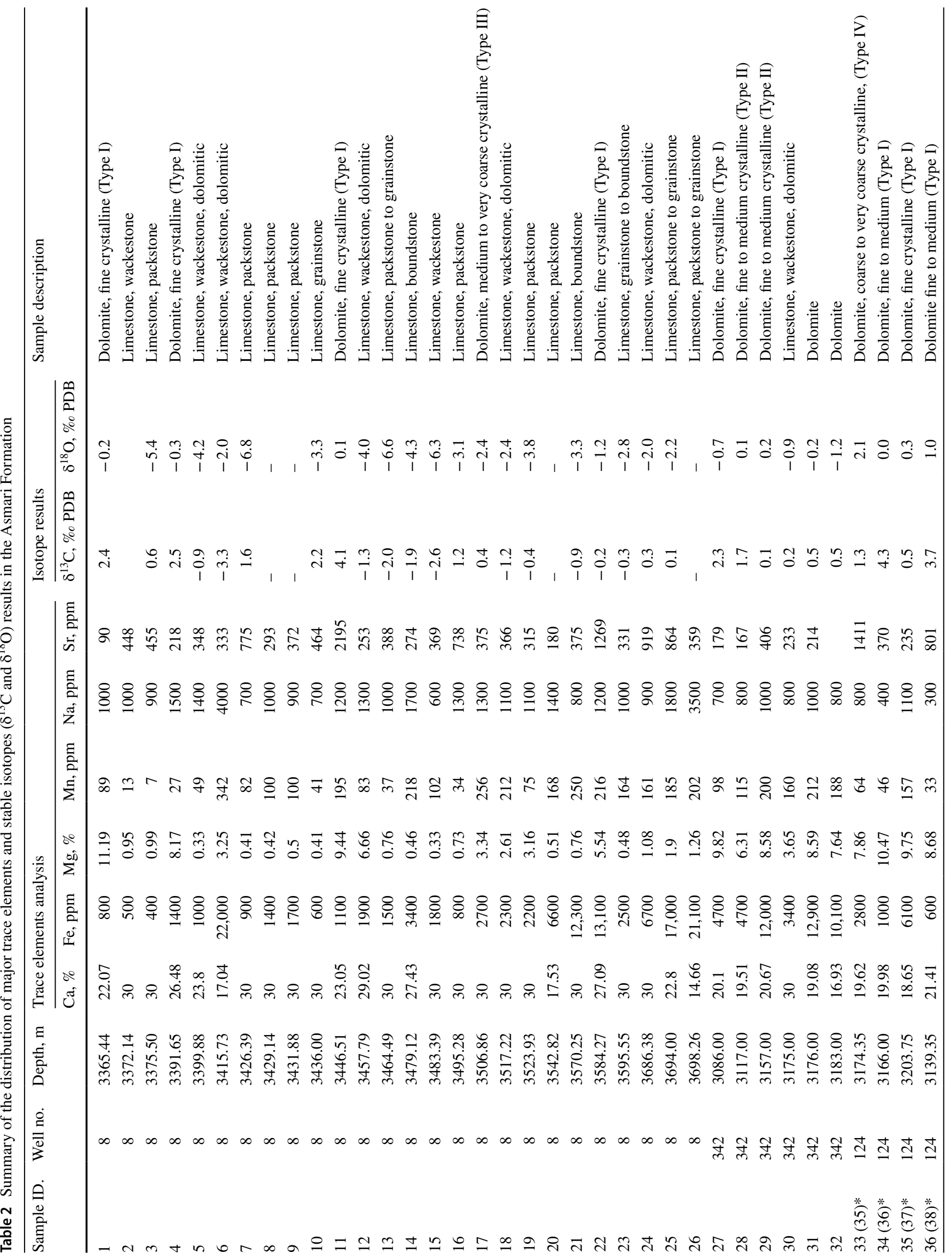




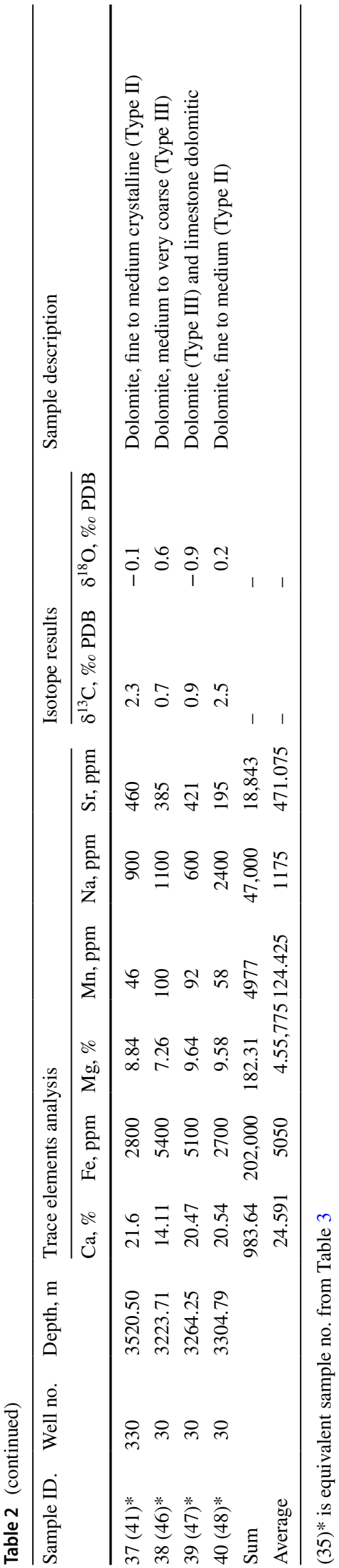

et al. 2010). Oil expulsion and emplacement most likely happened during the late Miocene to Holocene (approximately $5 \mathrm{Ma}$ ), (Ala 1982; Beydoun et al. 1992); hence, it can be concluded that much of the porosity evolved because of diagenetic processes before oil emplacement (Fig. 13). A discussion about the sequence of digenetic processes now follows.

Carbonates that form along continental margins and on carbonate platforms can eventually be buried to deeper depth. Assuming a normal geothermal gradient of $30{ }^{\circ} \mathrm{C} /$ $\mathrm{km}$, at burial depths of $2-3.5 \mathrm{~km}$, the formation temperature increases to $60-115{ }^{\circ} \mathrm{C}$. Hence, dissolution and precipitation reactions are enhanced (Swart 2015). Well data show that the Asmari Fm. is buried to depths more than $2 \mathrm{~km}$ (Fig. 2), so compaction as an early diagenetic process was an important factor that affected the Asmari Fm. from the early stages of deposition until the main orogeny phase during the Pliocene (Fig. 13). This process resulted in the porosity reduction with increase in drilling depth (Fig. 5). The abundance of stylolitization (pressure solution) in limestones and interlocked contacts of quartz grains in sandstones are the main evidences of compaction (Figs. 3a, 4). Stylolitization (pressure solution) has occurred, mainly parallel to the bedding with some oblique to vertical stylolitization in the upper and lower sections of the formation (Fig. 2). Dissolution of the host carbonates and loss of porosity occur during compaction (Rittenhouse 1971), and insoluble materials (including clay minerals, organic materials, pyrite, quartz grains) are left behind, leaving a distinct planar or ragged surface (Swart 2015). Stylolites usually act as permeability barriers; thus, they are of particular interest in reservoir characterization studies (Heap et al. 2014). However, stylolites are mainly oil stained, suggesting that stylolitization may have contributed to permeability enhance in the Asmari reservoir (Figs. 3a1, a2).

Subaerial diagenesis took place several times during deposition of the Asmari Fm. This is supported by evidences obtained from core studies and geochemical data (Figs. 2, $3 \mathrm{~d}$ and Table 2). Red-brown marl, together with shale and dolomite intervals, was observed at drilling depth $3415.75 \mathrm{~m}$ $\left(11,207^{\prime}\right)$, (Figs. 2, 3d2). Subaerial exposure resulted in abundant solution and vuggy porosity, with karsts features in limestones and dolostones at drilling depths $3415.75 \mathrm{~m}$, $3429 \mathrm{~m}, 3479 \mathrm{~m}$ and $3570.25 \mathrm{~m}$, (Figs. 2, 3c1, c2, d). These surfaces are equivalent to Type 1 sequence boundary surfaces suggested by Avarjani et al. (2015) (Fig. 2).

The most depleted values of $\delta^{18} \mathrm{O}$ and $\delta^{13} \mathrm{C}$ in limestones (Table 2 at depths 3415-3483 m) coincide with subaerial diagenetic zones (near proposed Type 1 or Type 2 sequence boundaries, Fig. 2). The depleted values of $\delta^{13} \mathrm{C}$ $(-3.3,-1.9,-0.9 \% 0)$ and $\delta^{18} \mathrm{O}(-2.0,-4.3,-3.3 \% o)$, and the evolution of solution and vuggy porosity at these intervals can be related to subaerial exposure (Fig. 2 and 

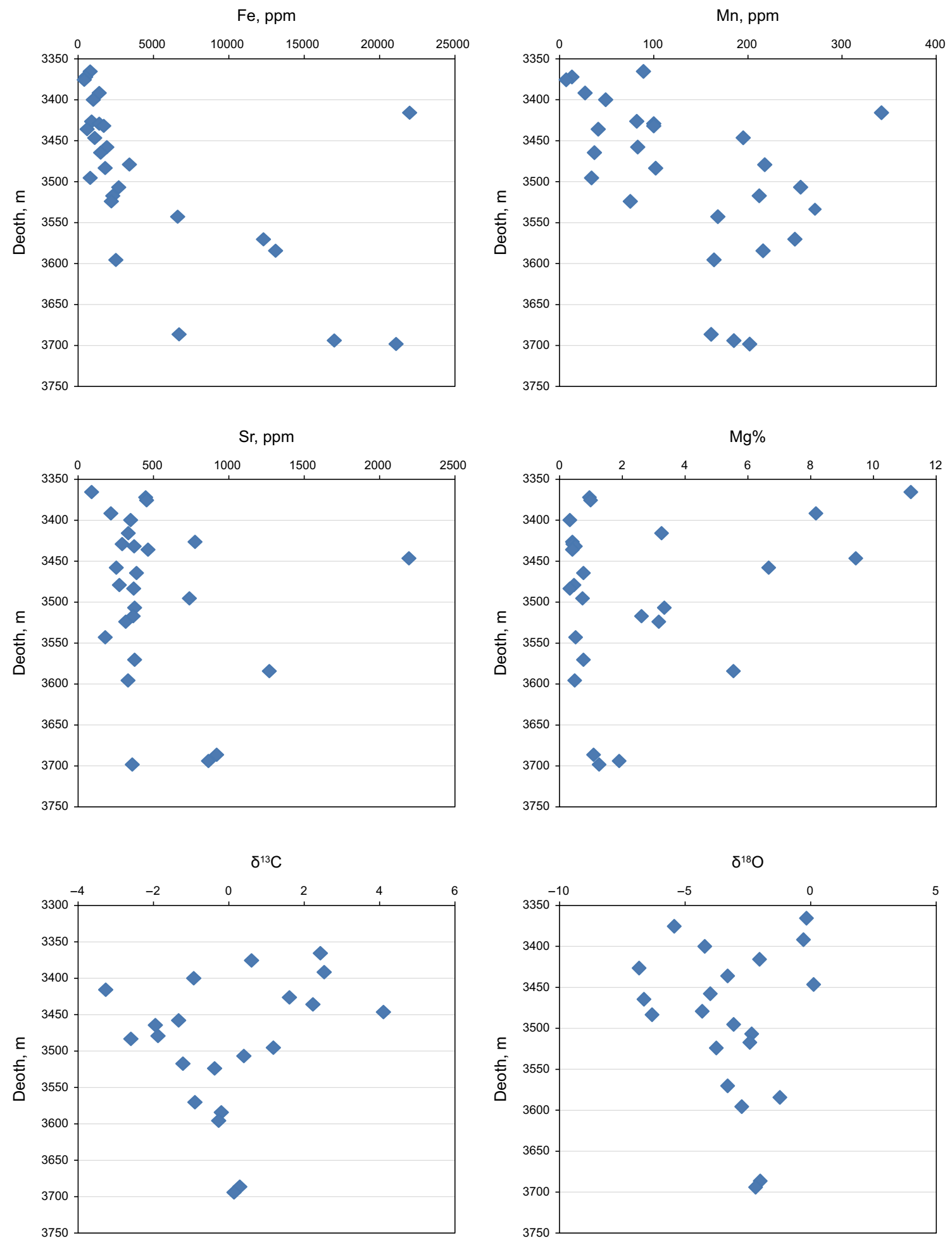

Fig. 8 Distribution of trace elements $\mathrm{Fe}, \mathrm{Mn}, \mathrm{Mg}, \mathrm{Sr}$ and stable isotopes $\delta^{18} \mathrm{O}, \delta^{13} \mathrm{C} \%$ with depth in well\#8

Table 2) (Budd 1997). The $\delta^{18} \mathrm{O}$ values that are lighter than the postulated marine calcite value $(-2.6 \%$ o PDB) are due to equilibration with non-marine waters (Adabi and Rao 1991), Hence, the depleted $\delta^{18} \mathrm{O}$ values of the above samples could be due to subaerial exposure and the effect of meteoric water. Based on the core study, some intervals are located below the Type I or Type II sequence boundaries (samples 6, 7, 11, 14 and 21; Figs. 2, 3d). 

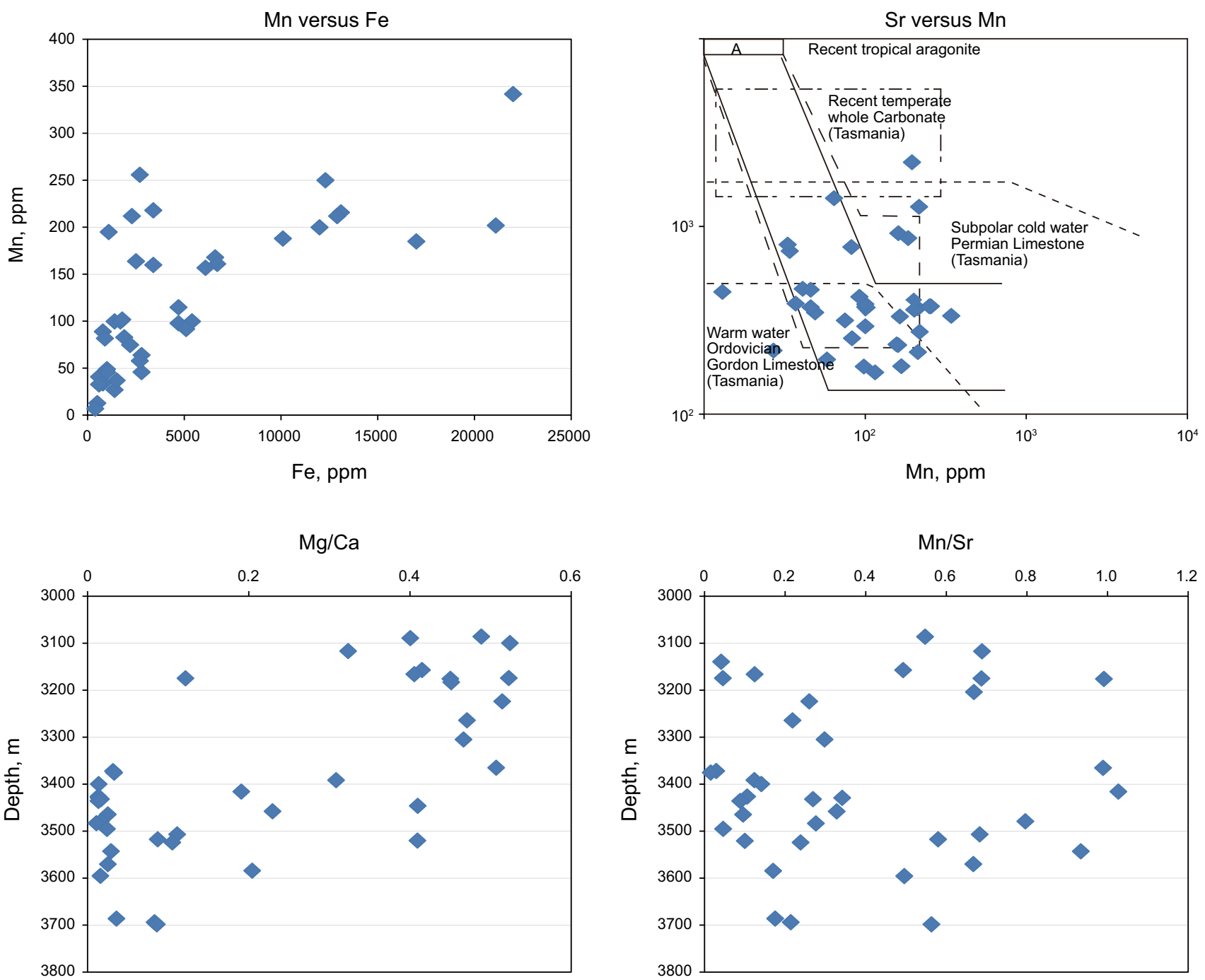

Fig. 9 General trend of trace elements proportion with depth in limestones and dolomites. Comparison of Sr/Mn ratio with analog curves (Adabi and Rao 1991)

The depletion of $\delta^{13} \mathrm{C}$ is characteristic of vadose diagenetic media, where the soil $\mathrm{CO}_{2}$ enrichment in ${ }^{12} \mathrm{C}$ occurs because of decomposition of organic matter (Adabi and Rao 1991). The depleted $\delta^{18} \mathrm{O}$ and $\delta^{13} \mathrm{C}$ values could also be attributed to temperature increase and preservation of organic materials (Azmy et al. 2001) (Fig. 8). The $\delta^{13} \mathrm{C}$ values in phreatic, meteoric calcite approach marine levels due to increasing rock-water interaction (Meyers and Lohmann 1985; Lohmann 1988). Trace element (e.g., Mn and $\mathrm{Fe}$ ) concentrations show a co-variant relationship with $\delta^{13} \mathrm{C}$ values, but a weak correlation with $\delta^{18} \mathrm{O}$ values (Fig. 8). This correlation could be due to effect of vadose diagenetic zone. Some samples of more positive $\delta^{13} \mathrm{C}$ (up to $+4.28 \%$ PDB) and $\delta^{18} \mathrm{O}$ values close to marine equilibrium (Fig. 12) may reflect marine diagenetic reactions (Braithwaite and Camoin 2011).
Cementation as a very important process has occurred in the Asmari Fm. in different environments from subaerial, freshwater vadose, sabkha saline, marine and shallow to deep burial. Calcite and anhydrite cementation (Figs. 3b1, b2, b5) are more frequent in limestones, but dolomite and silica cements (Figs. 3b3, b4) can also be seen in sandstone intervals. Syntaxial overgrowth, concave meniscus and isopachous equant spary calcite cements (Fig. 3b4, b6, b8, c2) suggest vadose and freshwater phreatic zones (Halley and Harris 1979). Solution of quartz grains and precipitation of overgrowth silica cements could be evidence of shallow to burial diagenesis of sandstones (Fig. 3b8) (Walderhaug et al. 2009; Swart 2015). The blocky cement may be comprised of partly early, near-surface cement (related to exposure) and partly late (burial) cement, which may have formed as a result of dissolution along stylolites and fractures (Fig. 3b6, c4). This process could have started at the beginning of the 

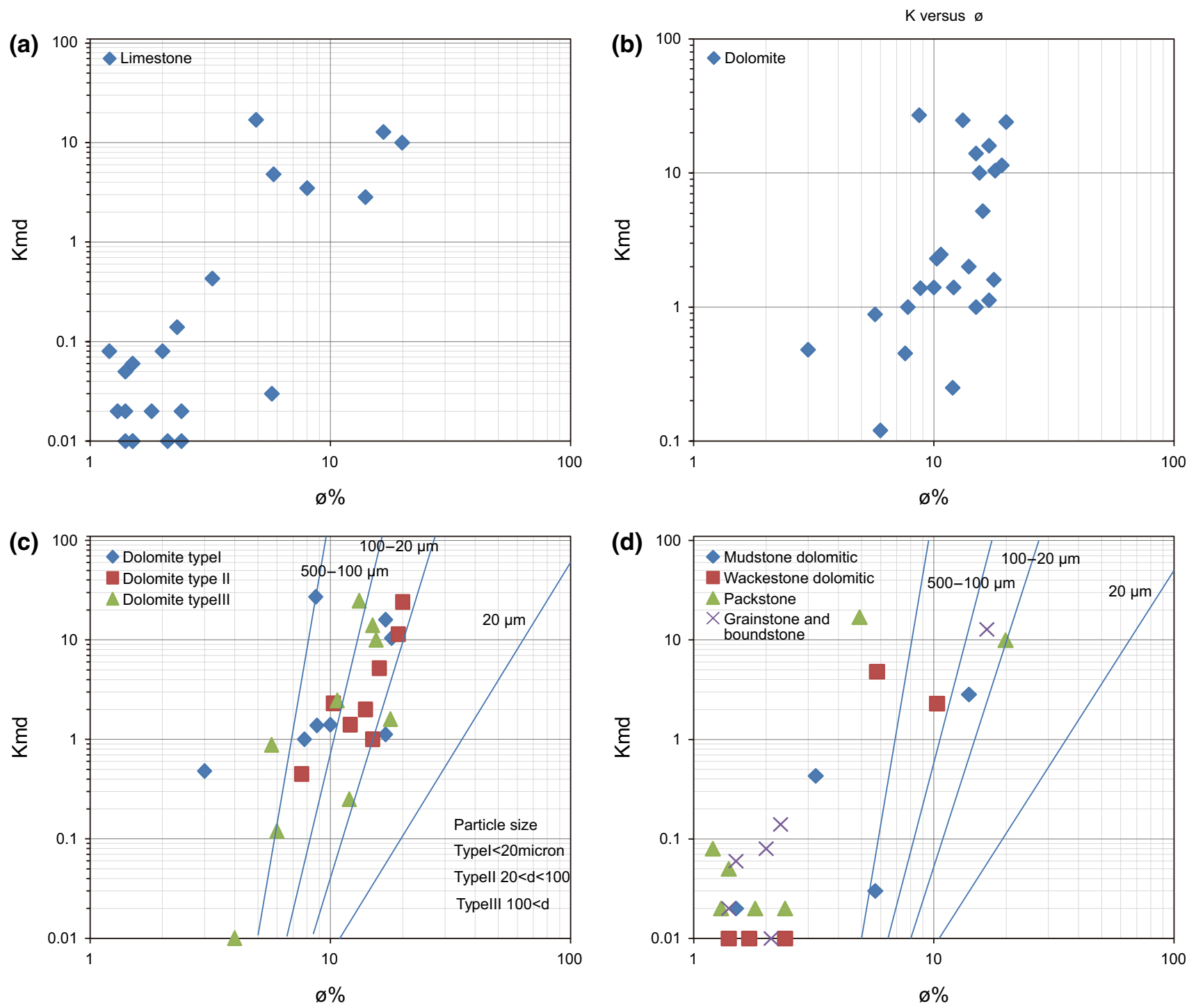

Fig. 10 Shows the relationship of porosity and permeability in the Asmari Formation. a Limestones, $\mathbf{b}$ dolomites cross-plots; $\mathbf{c}, \mathbf{d}$ show the relationship between petrophysical properties (porosity and permeability) of dolomites and limestones with the curves for standard particle size in uniformly cemented non-vuggy carbonates (Lucia 1983 and 1995)

Asmari Fm. deposition and lasted until oil migrated into the reservoir (Fig. 13).

The Asmari Fm. has been affected by four phases of dolomitization (Fig. 6d, CL). The rate of dolomitization increases from lower to the upper parts of the Asmari carbonate succession. This is supported by increasing $\mathrm{Mg} / \mathrm{Ca}$ ratios with a reduction in depth (Fig. 9). The dolomites of the Asmari Fm. are categorized as evaporitic because of their high concentrations of $\mathrm{Na}(2500 \mathrm{ppm}>\mathrm{Na}>700 \mathrm{ppm})$ and sulfate (10,000 ppm $>$ S $>900 \mathrm{ppm})$ (Staudt et al. 1993). The first phase (Phase I) of dolomitization is an early stage, which is documented by very fine, crystalline, unimodal dolomite (Type I with $d<20 \mu \mathrm{m}$ ) (Fig. 6a) and expresses pervasive replacement dolomitization that occurred in supratidal to sabkha and restricted supersaline environments (Budd 1997; Warren 2000).This phase of dolomitization occurred in muddy facies, such as mudstones, wackestones and mud-dominated packstone dolomites in grainy facies (cf. Al-Aasm 2000; Aqrawi et al. 2006). Some dolostone samples (e.g., No. 1, 4 and 11, Table 2) from the upper section of the Asmari Fm. show characteristics of this type of dolomite, with red luminescence, positive values of $\delta^{13} \mathrm{C}$ $(+2.4 \%$ o $+2.5 \%$ and $+4.1 \% \circ)$, and near zero values of $\delta^{18} \mathrm{O}$ PBD $(-0.2 \% o,-0.3 \% o$ and $+0.1 \%$ ) (Tables 1, 2, Fig. 6a). This phase mainly took place during lower Miocene (Burdigalian or later).

Pervasive dolomitization phases (II and III) were formed in a burial environment and high temperature conditions 
(a)

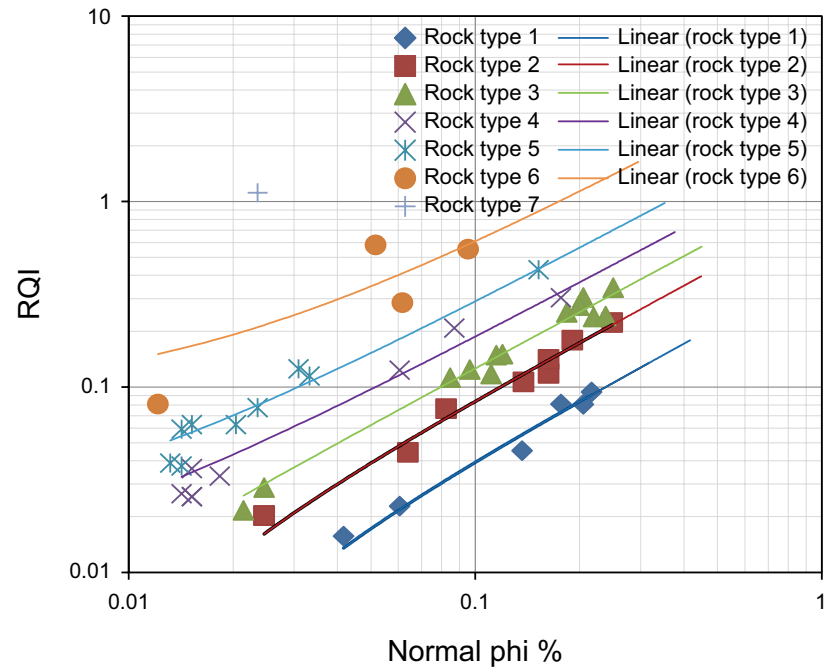

(b)

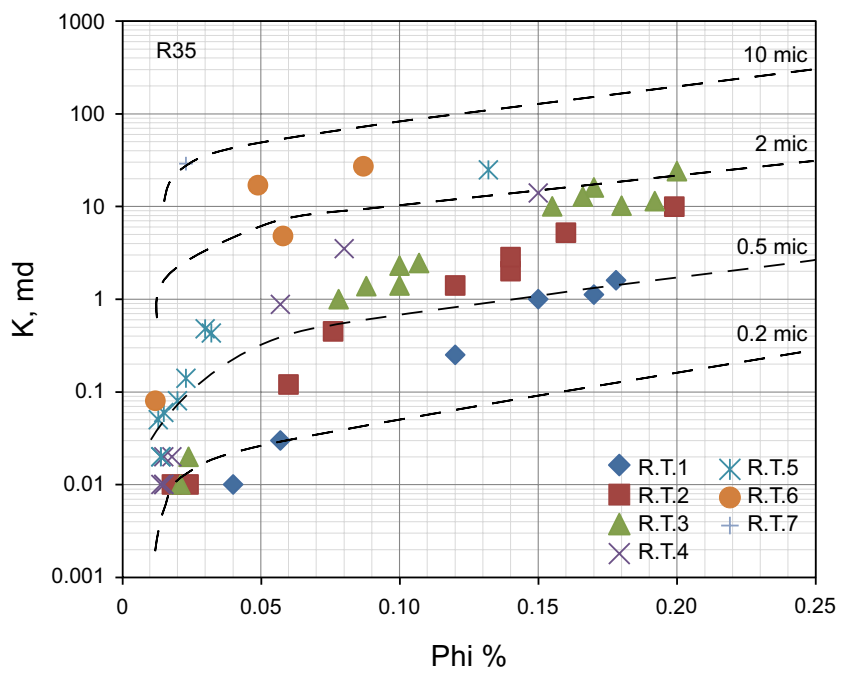

Fig. 11 a Reservoir rock types based on Flow Zone Index and Discrete Rock Type methods. b Semi-log cross-plot of porosity versus permeability shows reservoir flow units based on Winland R35 method

(Fig. 6b, c). The burial origin was suggested by recrystallization and formation of the coarse crystals, and a slight negative shift in $\delta^{18} \mathrm{O}$ values (Al-Aasm et al. 2009). These dolomites may have been recrystallized by a later fluid (AlAasm 2000). Dolomites of Type II and Type III show positive values of $\delta^{13} \mathrm{C}(+0.1$ to +2.5$)$, depleted to near zero $\delta^{18} \mathrm{O}(-2.4$ to 0.2$)$, and yellow, red to dark luminescence (Fig. 6, Table 2). These two phases of dolomitization may have occurred during burial of the Asmari Fm. at depths of more than $2 \mathrm{~km}$ after deposition of the Aghajari Fm. in late Miocene.

Phase IV is the precipitation of medium to coarse dolomite crystals in fractures, and solution vuggy porosities. This phase comprises planar polymodal dolomite with positive values $(+1.7$ to +4.3$)$ of $\delta^{13} \mathrm{C}$ and $\delta^{18} \mathrm{O}(0.0$ to +2.3$)$, and orange to brown luminescence (Fig. 6d, Table 2). The enriched values of $\delta^{18} \mathrm{O}$ may show the evaporative origin of Mg-bearing fluids (Al-Aasm et al. 2009). Phase IV of dolomitization presumably occurred after the main Zagros folding and fracturing events, during late Miocene to Pliocene.

It is suggested that the reflux model can explain the fine crystalline, pervasive dolomites found mainly in the upper half successions of the Asmari Fm. This model also is supported by the presence of anhydrite nodules with dolomite (Figs. 2, 3a1, d2), and the texture of the muddy facies includes tidal flat (supratidal and intertidal) and subtidal/ lagoonal facies of the precursor limestone. Another possible model for dolomite formation is probably related to flush over of platform grainstones from the previous depositional cycle (particularly within the Middle Asmari Fm.) by condensed and evaporative solutions. Dolomitization of open-marine facies in the lower and middle sections of the
Asmari Fm. may have occurred during the later burial phase, when the compaction of the underlying Pabdeh marls and shales generated Mg-rich fluids. The presence of concentric overgrowth of dolomite crystals (crystal zoning) defined by cathodoluminescence can mark the replasive burial origin (Fig. 6d) (cf. Budd 1997).

In addition to invoking the reflux model to explain the fine crystalline dolomite (Type I), the mixing zone model is also suggested for the origin of dolomitization in the Asmari Fm. because of the covariance of $\delta^{18} \mathrm{O} \%$ and $\delta^{13} \mathrm{C} \%$ (Figs. 2, 8 and Table 2) (Budd 1997; Swart 2015). This fluid mixing can be the main mechanism for dolomitization near the subaerial exposure surfaces and sequence boundaries (Al-Aasm 2000). Petrographic studies show evidence of freshwater dissolution and development of dolomitization below the subaerial exposures (Figs. 2, 3c1, c2, d) (proposed sequence boundaries by Avarjani et al. 2015). During lowstand systems tract, percolation of freshwater into the underlaying carbonate beds and formation of a mixing zone with the seawater resulted in the pervasive dolomitisation (types II and III) of the Asmari Fm. Dolomite type IV may have precipitated because of percolation of the Mg-bearing fluids through fractures and vuggy porosities (Fig. 6d).

The variation of $\mathrm{Sr}$ concentrations (90-2195 ppm) in dolomites can be related to either depositional and digenetic conditions of mixed meteoric realms, or burial digenetic media with Sr-rich fluids (Table 2) (White and Al-Aasm 1997; Al-Aasm 2000) that could indicate dolomite formation in a water-buffered diagenetic system (Budd 1997). Other higher Sr concentrations in limestones (Table 2) may reflect the contribution of skeletal and non-skeletal aragonitic grains. Since the $\mathrm{Mn} / \mathrm{Sr}$ ratio is generally less than 3 


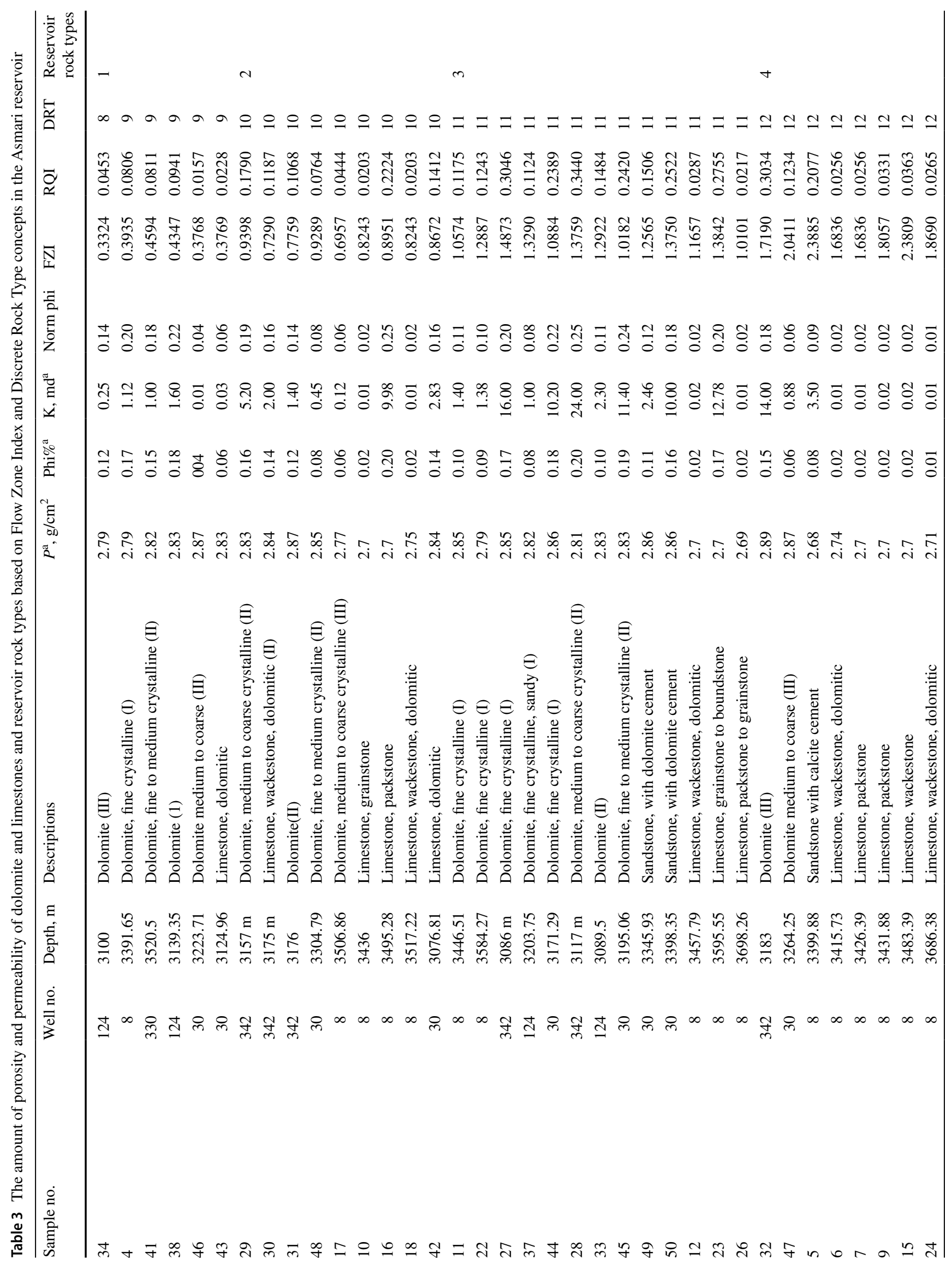




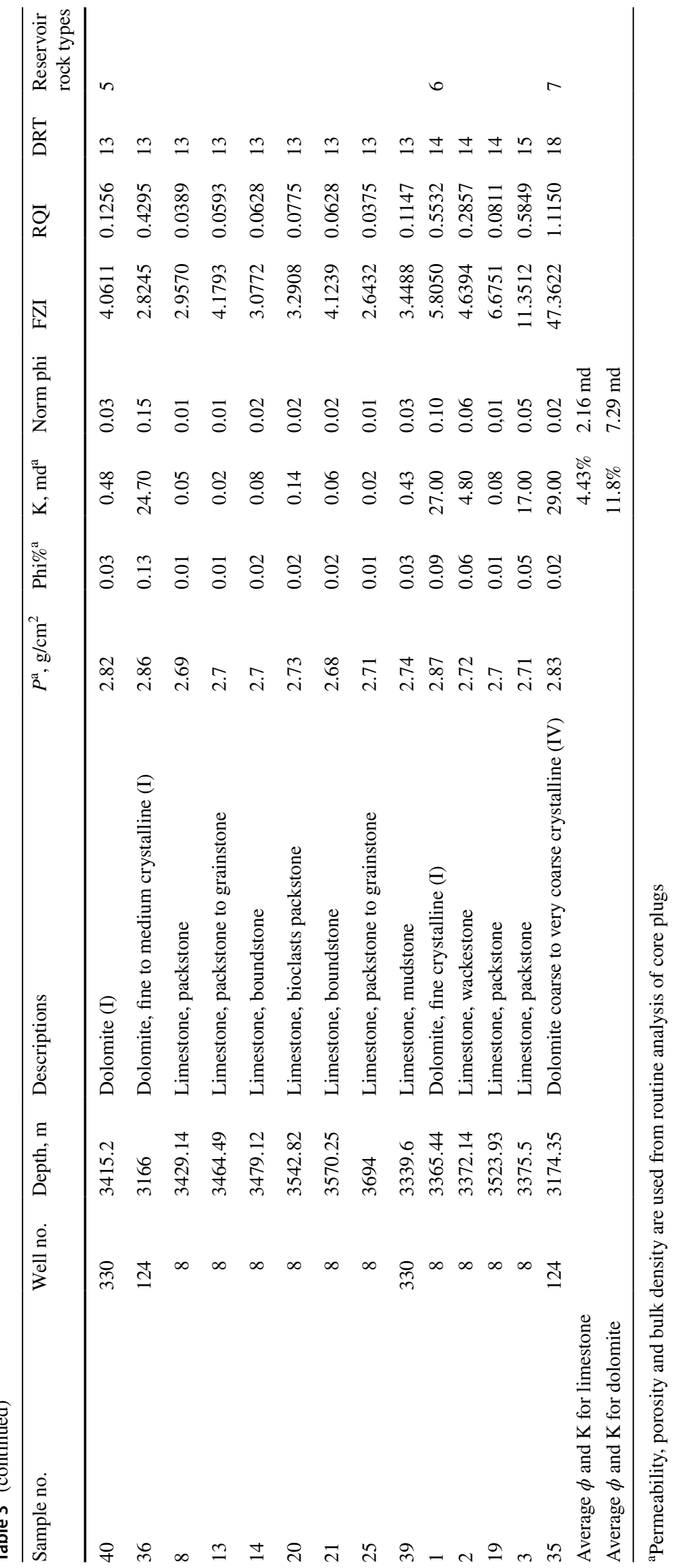




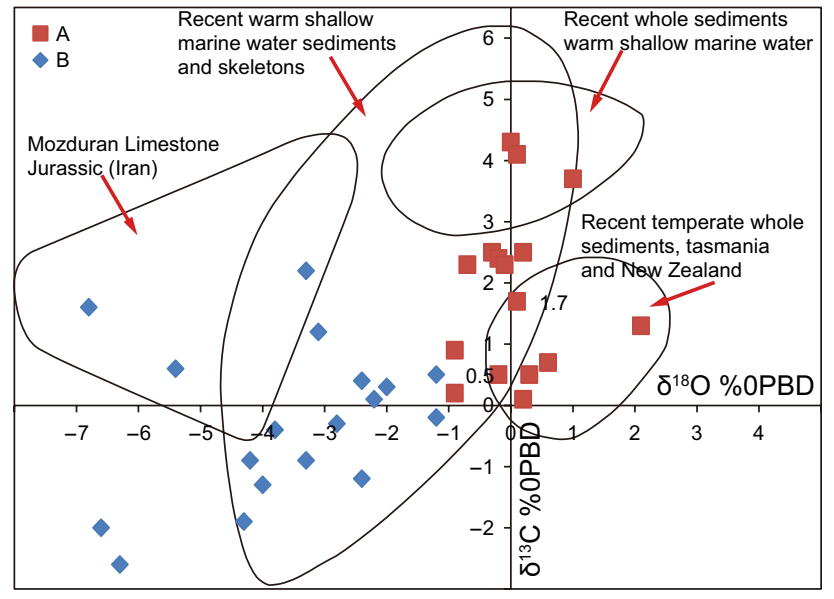

Fig. 12 Comparison of $\delta^{18} \mathrm{O}$ and $\delta^{13} \mathrm{C}$ values of dolomite and limestones from the Asmari Formation with the some analogs (James and Choquette 1983), (Adabi and Rao 1991). A=least altered samples (including limestone and dolomite); $\mathrm{B}=$ diagenetic samples

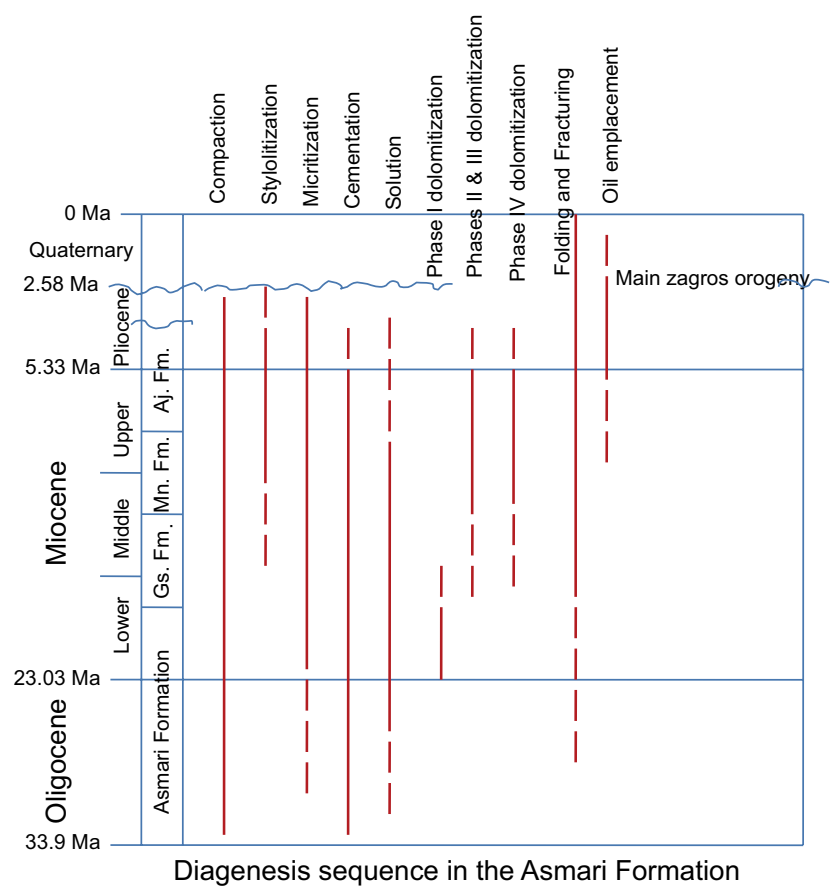

Fig. 13 Sequence of diagenesis processes and porosity evolution relative to each other, folding of Zagros belt and oil emplacement

(Fig. 9), it can be inferred that the original chemistry of the precursor carbonate is well preserved during diagenesis (Azmy et al. 2001).

\subsection{Reservoir quality}

Interparticle (intercrystalline and intergranular) (Fig. 3b, c5), moldic and vuggy porosities are the most outstanding porosity types of carbonates successions of the Asmari Fm (Fig. 3c1, c2, b1) (c.f. Lucia 1995). Moreover, intergranular porosity is the main type porosity for sandstone intervals (Fig. 3b4). The sizes of intercrystalline pore throats range mainly from micro- $(d<0.5 \mu \mathrm{m})$ to macro-porosity $(d \geq 5 \mu \mathrm{m})$ (Fig. 7) (Maliva et al. 2009).

Furthermore, most of the intercrystalline porosity of the dolomites is oil saturated (Fig. 6a, b).

Compaction and cementation are the main causes for reservoir quality destruction (Fig. 3a, a2, b5). Reduction in the Asmari reservoir porosity versus depth can be seen generally (Fig. 5). A large proportion of the primary intergranular porosities in grainstones and packstones are occluded by calcite and anhydrite cements (Fig. 3c2, b6), while anhydrite and dolomitic cements are the main cause of porosity reduction in sandstones (Fig. 3b3, b4, b5).

The petrophysical properties of selected limestone and dolomite core plug samples are presented in Table 3 . This dataset shows that the average porosity and permeability, respectively, are $4.4 \%$ and 2.16 md for limestones, and $11.80 \%$ and $7.29 \mathrm{md}$ for dolomites. Although a large increase in porosity (approximately 7.4\%) is related to dolomitization, there is a fairly good correlation between porosity and permeability for dolomites (Fig. 10b). This may be due to the closing of some pore throats by over dolomitization or precipitation of anhydrite cement (Lucia 1983).

On contrary to dolomites, limestone samples represent a good correlation between porosity and permeability (Fig. 10a) that reflects diagenesis is more positive for permeability preservation in limestones rather than dolomites, or it can be evidence of permeability preservation in limestones during diagenesis.

A cross-plot of porosity versus permeability, overlaid with standard curves of the relationship between petrophysical properties and particle size for uniformly cemented, nonvuggy carbonates (Lucia 1983), shows that Type II dolomites $(20<d<100 \mu \mathrm{m})$ match with the standard area for this particle size. However, Types I and III do not match with the standard area of the corresponding particle size (Fig. 10c). This deviation to the left of Type 1 dolomites may be due to porosity and permeability enhancement by dissolution and development of vuggy porosity (Fig. 10c). Interparticle porosities in Type I dolomite samples are mainly connected to each other by touching vugs that led to high effective porosities (Figs. 3c1, c2). The porosity and permeability of Type III dolomites were reduced due to cementation and over dolomitization, as if the plots of these samples deviated to the right (Figs. 6c, 10c).

The cross-plot of porosity and permeability in limestones (Fig. 10d) reveals that the petrophysical properties of the Asmari reservoir differ from the original rock texture.

Reservoir rock typing, based on FZI and DRT methods, illustrates that the reservoir hydraulic flow units do not 
necessarily follow the geological classification and texture of carbonate reservoir rocks (Table 3). Therefore, it seems that diagenesis is the main controlling factor of the carbonate reservoir quality. Reservoir rock type 3 (RRT3) consists of Type I and II dolomites as well as sandstones with dolomitic cement (Table 3 ), indicating the best reservoir quality (Fig. 11).

\section{Conclusions}

Seven hydraulic flow units were distinguished using FZI (Flow Zone Index) and DRT (Discrete Rock Type) methods. Rock types 1, 2 and 3 mainly consist of dolomite, while rock types 4, 5, 6 and 7 encompass a variety of limestone textures (mudstone, wackestone, packstone, grainstone, boundstone) and some dolomite samples. Cross-plots of petrophysical properties and analysis of FZI show that the main controlling factors of the reservoir heterogeneity and quality in the Asmari Fm. are diagenetic processes, especially, cementation, dolomitization and dissolution. Core plug data reveal that the porosity and permeability of the Asmari reservoir increased due to dolomitization (average increase of 7.4\% and $5 \mathrm{md}$, respectively) as the most effective diagenetic factor influencing reservoir quality enhancement.

Four types of dolomites have been recognized in the Asmari Fm.: (1) Type I, very fine to fine crystalline dolomite (crystal size $<20 \mu \mathrm{m}$ ); (2) Type II, fine to medium crystalline $(<100 \mu \mathrm{m})$, polymodal, planar to planar-s secondary pervasive dolomite; (3) Type III, medium to coarse crystalline, polymodal, subhedral to xenotopic; and (4) Type IV, medium to very coarse crystalline, dolomitic cement or saddle dolomite. Type I dolomite would have been formed in restricted sabkha and supersaline environments, while the other types would have been formed in medium to deep burial and high temperature conditions. Based on dissolution porosity, the development of dolomitization under subaerial exposures and Type 1 sequence boundaries the mixing zone model is proposed for the main dolomitization phase in the Asmari Fm.

However, brine reflux, seepage reflux and tidal pumping of seawater models are also proposed to explain dolomitization in some other intervals of the Asmari Fm.

Stable isotope and trace elements analyses indicated that the carbonate successions of the Asmari Fm. were deposited in warm, shallow marine environments under a saline evaporative condition.

Acknowledgements We wish to thank the National Iranian South Oil Company for providing well core samples, core analysis results and log data. We would also like to appreciate Ferdowsi University of Mashhad for their logistic and financial support during this study (Project No. 3/27852). Also, ISA would like to acknowledge NSERC for their support. We also acknowledge honorable referees for their review and suggestions, which improved the quality of the manuscript significantly.

Open Access This article is licensed under a Creative Commons Attribution 4.0 International License, which permits use, sharing, adaptation, distribution and reproduction in any medium or format, as long as you give appropriate credit to the original author(s) and the source, provide a link to the Creative Commons licence, and indicate if changes were made. The images or other third party material in this article are included in the article's Creative Commons licence, unless indicated otherwise in a credit line to the material. If material is not included in the article's Creative Commons licence and your intended use is not permitted by statutory regulation or exceeds the permitted use, you will need to obtain permission directly from the copyright holder. To view a copy of this licence, visit http://creativecommons.org/licenses/by/4.0/.

\section{References}

Abedini A. Statistical evaluation of reservoir rock type in a carbonate reservoir. In: Society of Petroleum Engineers Annual Technical Conference and Exhibition. 2011. https://doi.org/10.2118/15235 9-STU.

Adabi MH, Rao CP. Petrographic and geochemical evidence for original aragonite mineralogy of Upper Jurassic carbonates (Mozduran Formation), Sarakhs area, Iran. Sediment Geol. 1991;72:253-67. https://doi.org/10.1016/0037-0738(91)90014-5.

Adams C, Bourgeois E. Asmari Biostratigraphy. Geological and Exploration Div. Iranian Oil Offshore Company Report 1074. Unpublished internal Report of the NIOC. 1967.

Al-Aasm IS. Chemical and isotopic constraints for recrystallization of sedimentary dolomites from the Western Canada Sedimentary Basin. Aquat Geochem. 2000;6:227-48. https://doi. org/10.1023/A:100961122.

Al-Aasm I, Ghazban F, Ranjbaran M. Dolomitization and related fluid evolution in the Oligocene-Miocene Asmari Formation, Gachsaran area, SW Iran: petrographic and isotopic evidence. J Pet Geol. 2009;32:287-304. https://doi.org/10.111 $1 / j .1747-5457.2009 .00449 . x$.

Ala M. Chronology of trap formation and migration of hydrocarbons in Zagros sector of southwest Iran. AAPG Bull. 1982;66:1535-41.

Allahkarampour Dill M, Seyrafian A, Vaziri-Moghaddam H. The Asmari Formation, north of the Gachsaran (Dill anticline), southwest Iran: facies analysis, depositional environments and sequence stratigraphy. Carbonate Evaporites. 2010;25:145-60. https://doi. org/10.1007/s13146-010-0021-6.

Amaefule JO, Altunbay M, Tiab D, Kersey DG, Keelan DK. Enhanced reservoir description: using core and log data to identify hydraulic (flow) units and predict permeability in uncored intervals/wells. In: Society of Petroleum Engineers annual technical conference and exhibition. 1993. https://doi.org/10.2118/26436-MS.

Aqrawi A, Keramati M, Ehrenberg S, Pickard N, Moallemi A, Svånå $\mathrm{T}$, et al. The origin of dolomite in the Asmari Formatiom (Oligocene-Lower Miocene), Dezful Embayment, SW Iran. J Pet Geol. 2006;29:381-402. https://doi.org/10.111 1/j.1747-5457.2006.00381.x.

Archie GE. Classification of carbonate reservoir rocks and petrophysical considerations. AAPG Bull. 1952;36:278-98. https://doi. org/10.1306/3D9343F7-16B1-11D7-8645000102C1865D.

ArRajehi A, McClusky S, Reilinger R, Daoud M, Alchalbi A, Ergintav $\mathrm{S}$, et al. Geodetic constraints on present-day motion of the Arabian Plate: Implications for Red Sea and Gulf of Aden rifting. Tectonics. 2010;29:TC3011. https://doi.org/10.1029/2009tc002482. 
Askari AA, Behruz T. A fully integrated method for dynamic rock type characterization development in one of Iranian off-shore oil reservoir. J Chem Pet Eng Univ Tehran. 2011;45(2):83-96. https ://doi.org/10.22059/jchpe.2011.1510.

Avarjani S, Mahboubi A, Moussavi-Harami R, Amiri-Bakhtiar H, Brenner RL. Facies, depositional sequences, and biostratigraphy of the Oligo-Miocene Asmari Formation in Marun oilfield, North Dezful Embayment, Zagros Basin, SW Iran. Palaeoworld. 2015;24:336-58. https://doi.org/10.1016/j.palwor.2015.04.003.

Azmy K, Veizer J, Misi A, de Oliveira TF, Sanches AL, Dardenne MA. Dolomitization and isotope stratigraphy of the Vazante Formation, São Francisco Basin, Brazil. Precambrian Res. 2001;112:303-29. https://doi.org/10.1016/S0301-9268(01)00194-2.

Banner JL, Hanson G, Meyers W. Water-rock interaction history of regionally extensive dolomites of the Burlington-Keokuk Formation (Mississippian): isotopic evidence. In: Sedimentology and Geochemistey of Dolostones, vol. 43. Society of Economic Mineralogistes and Palaeontologists; 1988. p. 97-113.

Beydoun Z, Clarke MH, Stoneley R. Petroleum in the Zagros basin: a late tertiary foreland basin overprinted onto the outer edge of a vast hydrocarbon-rich paleozoic-mesozoic passive-margin shelf: chapter 11. In: Macqueen RW, Leckie DA, editors. M55: Foreland Basins and Fold Belts, AAPG, Memoir 55. Tulsa, OK: AAPG; 1992. https://doi.org/10.1306/M55563.

Bize-Forest N, Baines V, Boyd A, Moss A, Oliveria R. Carbonate reservoir rock typing and the link between routine core analysis and special core analysis. In: International Symposium of the Society of Core Analysts; Avignon, France, 2014.

Braithwaite CJ, Camoin GF. Diagenesis and sea-level change: lessons from Moruroa, French Polynesia. Sedimentology. 2011;58:25984. https://doi.org/10.1111/j.1365-3091.2010.01182.x.

Budd D. Cenozoic dolomites of carbonate islands: their attributes and origin. Earth-Sci Rev. 1997;42:1-47. https://doi.org/10.1016/ S0012-8252(96)00051-7.

Dunham RJ. Classification of carbonate rocks according to depositional textures. In: Ham WE, editor Classification of Carbonate Rocks. AAPG Mem 1. 1962; p. 108-121. https://doi.org/10.1306/M1357.

Ehrenberg SN, Pickard NAH, Laursen GV, Monibi S, Mossadegh ZK, Svånå TA, et al. Strontium isotope stratigraphy of the Asmari Formation (Oligocene-lower Miocene), SW Iran. J Pet Geol. 2007;30:107-28. https://doi.org/10.1111/j.1747-5457.2007.00107.x.

Embry AF, Klovan JE. A late Devonian reef tract on northeastern Banks Island, NWT. Bull Can Petrol Geol. 1971;19:730-81. https://doi. org/10.11575/PRISM/22817.

Falcon N. Southern Iran: Zagros Mountains. Geol Soc Lond Spec Publ. 1974;4:199. https://doi.org/10.1144/GSL.SP.2005.004.01.11.

Flügel E, editor. Microfacies data: fabrics. In: Microfacies of carbonate rocks. Analysis, interpretation and aplication. New York: Springer; 2004. 976 p. https://doi.org/10.1007/978-3-662-08726-8_5.

Halley RB, Harris PM. Fresh-water cementation of a 1000-year-old oolite. J Sediment Res. 1979;49:969-88. https://doi.org/10.1306/212F7 892-2B24-11D7-8648000102C1865D.

Heap MJ, Baud P, Reuschlé T, Meredith PG. Stylolites in limestones: barriers to fluid flow? Geology. 2014;42:51-4. https://doi.org/10.1130/ G34900.1.

Homke S, Vergés J, Van Der Beek P, Fernàndez M, Saura E, Barbero $\mathrm{L}$, et al. Insights in the exhumation history of the NW Zagros from bedrock and detrital apatite fission-track analysis: evidence for a long-lived orogeny. Basin Res. 2010;22:659-80. https://doi.org/10. 1111/j.1365-2117.2009.00431.x.

James GA, Wynd JG. Stratigraphic nomenclature of Iranian oil consortium agreement area. AAPG Bull. 1965;49:2182-245.

James NP, Choquette PW. Diagenesis, 6. Limestones-the sea floor diagenetic environment. Geosci Can. 1983;10:162-79. https://journals. lib.unb.ca/index.php/GC/article/view/3353.
Kozeny J. Über kapillare leitung des wassers im boden: (aufstieg, versickerung und anwendung auf die bewässerung) Hölder-PichlerTempsky; 1927.

Laursen GV, Monibi S, Allan TL, Pickard NAH, Hosseiney A, Vincent B, Hamon Y, Van Buchem FSP, et al. The Asmari Formation revisited: changed stratigraphic allocation and new biozonation. In: First International Petroleum Conference and Exhibition, Shiraz, Iran. 2009. https://doi.org/10.3997/2214-4609.20145919.

Leturmy P, Molinaro M, de Lamotte DF. Structure, timing and morphological signature of hidden reverse basement faults in the Fars Arc of the Zagros (Iran). Geol Soc Lond Spec Publ. 2010;330:121-38. https://doi.org/10.1144/SP330.7.

Lohmann KC. Geochemical patterns of meteoric diagenetic systems and their application to studies of paleokarst. In: James NP, Choqutte PW, editors. Paleokarst. New York: Springer; 1988. p. 58-80. https ://doi.org/10.1007/978-1-4612-3748-8_3.

Lucia FJ. Petrophysical parameters estimated from visual description of carbonate rocks: a field classification of carbonate pore space. J Pet Technol. 1983;35:626-37. https://doi.org/10.2118/10073-PA.

Lucia FJ. Rock fabric/petrophysical classification of carbonate pore space for reservoir characterization. AAPG Bull. 1995;79:1275-300. https ://doi.org/10.1306/7834D4A4-1721-11D7-8645000102C1865D.

Maliva RG, Missimer TM, Clayton EA, Dickson J. Diagenesis and porosity preservation in Eocene microporous limestones, South Florida, USA. Sediment Geol. 2009;217:85-94. https://doi.org/10.1016/j. sedgeo.2009.03.011.

Meyers WJ, Lohmann KC. Isotope geochemistry of regionally extensive calcite cement zones and marine components in Mississippian limestones, New Mexico. In: The Society of Economic Paleontologists and Mineralogists (SEPM) Carbonate Cements (SP36). 1985.

Motiei H. Stratigraphy of Zagros. Treatise on the Geology of Iran (in Persian). Geological Survey of Iran, Tehran. 1993; p. 536.

Mouthereau F, Lacombe O, Meyer B. The Zagros folded belt (Fars, Iran): constraints from topography and critical wedge modelling. Geophys J Int. 2006;165:336-56. https://doi.org/10.1111/j.1365246X.2006.02855.x.

Rahmani A, Vaziri-Moghaddam H, Taheri A, Ghabeishavi A. A model for the paleoenvironmental distribution of larger foraminifera of Oligocene-Miocene carbonate rocks at Khaviz Anticline, Zagros Basin, SW Iran. Hist Biol. 2009;21:215-27. https://doi.org/10.1080/08912 960903461296.

Ranjbaran M, Fayazi F, Al-Aasm I. Sedimentology, depositional environment and sequence stratigraphy of the Asmari Formation (Oligocene-Lower Miocene), Gachsaran Area, SW Iran. Carbonate Evaporites. 2007;22:135-48. https://doi.org/10.1007/BF03176243.

Rao CP. Geochemistry of temperate-water carbonates, Tasmania, Australia. Mar Geol. 1986;71:363-70. https://doi.org/10.1016/00253227(86)90078-2.

Rittenhouse G. Pore-space reduction by solution and cementation. AAPG Bull. 1971;55:80-91.

Sepehr M, Cosgrove J. Structural framework of the Zagros fold-thrust belt, Iran. Mar Pet Geol. 2004;21:829-43. https://doi.org/10.1016/j. marpetgeo.2003.07.006.

Seyrafian A, Vaziri-Moghaddam H, Arzani N, Taheri A. Facies analysis of the Asmari Formation in central and north-central Zagros basin, southwest Iran: biostratigraphy, paleoecology and diagenesis. Rev Mex Cienc Geol. 2011;28:439-58.

Shabafrooz R, Mahboubi A, Vaziri-Moghaddam H, Ghabeishavi A, Moussavi-Harami R. Depositional architecture and sequence stratigraphy of the Oligo-Miocene Asmari platform; Southeastern Izeh Zone, Zagros Basin, Iran. Facies. 2015;61:423. https://doi. org/10.1127/njgpa/2015/0483.

Sherkati S, Letouzey J. Variation of structural style and basin evolution in the central Zagros (Izeh zone and Dezful Embayment), Iran. Mar Pet Geol. 2004;21:535-54. https://doi.org/10.1016/j.marpe tgeo.2004.01.007. 
Sherkati S, Molinaro M, de Lamotte DF, Letouzey J. Detachment folding in the Central and Eastern Zagros fold-belt (Iran): salt mobility, multiple detachments and late basement control. J Struct Geol. 2005;27:1680-96. https://doi.org/10.1016/j.jsg.2005.05.010.

Sibley DF, Gregg JM. Classification of dolomite rock textures. J Sediment Res. 1987;57:967-75. https://doi.org/10.1306/212F8CBA-2B2411D7-8648000102C1865D.

Staudt WJ, Oswald EJ, Schoonen MAA. Determination of sodium, chloride and sulfate in dolomites: a new technique to constrain the composition of dolomitizing fluids. Chem Geol. 1993;107:97-109. https ://doi.org/10.1016/0009-2541(93)90104-Q.

Swart PK. The geochemistry of carbonate diagenesis: the past, present and future. Sedimentology. 2015;62:1233-304. https://doi. org/10.1111/sed.12205.

Van Buchem F, Allan T, Laursen G, Lotfpour M, Moallemi A, Monibi S et al. Sequence stratigraphy and $\mathrm{Sr}$ isotope stratigraphy of the OligoMiocene deposits in the Dezful embayment (Asmari and Pabdeh Formations, SW Iran)-implications for reservoir characterisation. In: 1st EAGE International Petroleum Conference and Exhibition, Shiraz, Iran. 2009. https://doi.org/10.3997/2214-4609.20145917.

Van Buchem F, Allan T, Laursen G, Lotfpour M, Moallemi A, Monibi S, et al. Regional stratigraphic architecture and reservoir types of the Oligo-Miocene deposits in the Dezful Embayment (Asmari and Pabdeh Formations) SW Iran. Geol Soc Lond Spec Publ. 2010;329:219 63. https://doi.org/10.1144/sp329.10.
Vaziri-Moghaddam H, Kimiagari M, Taheri A. Depositional environment and sequence stratigraphy of the Oligo-Miocene Asmari Formation in SW Iran. Facies. 2006;52:41-51. https://doi.org/10.1007/s1034 7-005-0018-0.

Walderhaug O, Lander RH, Bjørkum PA, Oelkers EH, Bjørlykke $\mathrm{K}$, Nadeau PH. Modelling quartz cementation and porosity in reservoir sandstones: examples from the norwegian continental shelf. In: Worden R, Morad S, editors. Quartz cementation in sandstones. Hoboken: Blackwell Publishing Ltd.; 2009. p. 39-49.

Warren J. Dolomite: occurrence, evolution and economically important associations. Earth-Sci Rev. 2000;52:1-81. https://doi. org/10.1016/S0012-8252(00)00022-2.

White T, Al-Aasm IS. Hydrothermal dolomitization of the mississippian upper Debolt Formation, Sikanni gas field, northeastern British Columbia, Canada. Bull Can Pet Geol. 1997;45:297-316.

Xu C, Heidari Z, Torres-Verdín C. Rock classification in carbonate reservoirs based on static and dynamic petrophysical properties estimated from conventional well logs. In: Society of Petroleum Engineers Annual Technical Conference and Exhibition held in San Antonio, Texas, USA. 2012. https://doi.org/10.2118/15999 1-MS.

Zabihi Zoeram F, Vahidinia M, Mahboubi A, Amiri Bakhtiar H. Facies analysis and sequence stratigraphy of the Asmari Formation in the northern area of Dezful Embayment, south-west Iran. Stud UBB Geol. 2013;58:45-56. https://doi.org/10.5038/1937-8602.58.1.4. 